\title{
Design an Attendance System Using Global Positioning System (GPS) Technology at PT. Cipta Anugrah Musi
}

\author{
Muhammad Faisal \\ Universitas Bina Darma \\ Email:mfaisal@gmail.com
}

\begin{abstract}
The purpose of this research is to design an attendance system using Global Positioning System (GPS) technology, as a useful solution. At PT. Cipta Anugrah Musi for the marketing staff to still be able to do attendance without using a fingerprint attendance machine. Based on the results of research and discussion on the marketing employee attendance monitoring system in the form of this android mobile, the following conclusions can be drawn. From the black box testing that has been done, it can be concluded that the employee attendance monitoring system can run well and there are no problems. GPS technology can provide information on where to take employee photos so that it is easy to find out the position of the employee's absence at that time to avoid cheating in attendance.
\end{abstract}

Keywords: GPS, attendance system

\section{Pendahuluan}

Manajemen pemasaran karyawan PT. Cipta Anugrah Musi menerapkan prosedur absensi sidik jari setiap karyawan keluar masuk kantor tanpa terkecuali tenaga pemasaran. Dengan adanya peraturan ini, tenaga pemasaran merasa keberatan di karenakan dalam satu hari kerja, tenaga pemasaran dapat keluar masuk kantor lebih dari tiga kali di karenakan ada enam perumahan dari PT. Cipta Anugrah Musi yaitu, Griya Duta Mas, Duta Hill Residence, Perumahan Kirana Permai, Duta Tanah Mas, Griya Duta Lestari, Griya Duta Gandus, sementara permasalahan yang sering terjadi adalah lupa melakukan presensi, sehingga tenaga pemasaran mendapatkan teguran dari atasan. Sebagai solusi atas permasalahan yang terjadi, perlu adanya system presensi dengan memanfaatkan teknologi Global Positioning System(GPS) dengan menggunakan system ini, tenaga pemasaran tidak perlu lagi melalukan presensi dengan sidik jari pada mesin presensi, melainkan hanya perlu membawa perangkat smartphone yang dilengkapi dengan GPS sebagai media untuk mencatat kehadiran karyawan di lokasi area kantor sebagai status masuk kantor dan mencatat status keluar kantor saat tenaga pemasaran meninggalkan kantor. Manajemen kinerja bertujuan untuk menciptakan budaya pada individu dan kelompok dalam memikul tanggung jawab bagi usaha dalam meningkatkaan proses kerja dan kemampuan yang berkesinambungan yang menggunakan presensi sebagai salah satu standar utama penilaian kedisiplinan.

Presensi sebagai tolak ukur utama untuk menjunjung tinggi nilai kedisiplinan karyawan pemasaran. Dalam penerapannya di berbagai perusahaan presensi terbagi menjadi beberapa macam, yakni mesin presensi kartu Presensi adalah kehadiran karyawan perusahaan sebagai standar untuk menilai kedisiplinan anggotanya berdasarkan kuantitas kehadiran presensi berbeda dengan absensi yang berarti ketidakhdiran, absensi adalah suatu cara yang dilakukan untuk menghitung jumlah ketidakhadiran anggotanya. Namun 
pada kenyataannya sering kali kata absensi di gunakan sebagai standar kuantitas kehadiran, presensi finger print. Perangkat ini memanfaatkan Global Positioning System yang dapat melacak informasi spasial karyawan atau pegawai dalam area tempat bekerja system akan membatasi cakupan area kerja berupa titik koordinat yang diambil langsung dari Google Maps. Ketika perangkat aktif maka system akan mengirimkan informasi spasial karyawan dengan memanfaatkan Location Based Service dan server akan mendapat koordinat dimana posisi karyawan yang bersangkutan berada. Sehingga apabila karyawan berada pada area maka karyawan dinyatakan check-in oleh system dan karyawan akan memperoleh notifikasi telah melakukan presensi. Ketika karyawan berada di area non maka system akan mengirimkan notifikasi pada karyawan bahwa perangkat keluar dari area.

Berdasarkan latar belakang yang telah diuraikan di atas identifikasi masalah untuk melacak aktifitas posisi karyawan selama jam kerja secara real-time menggunakan smartphone Android.Tenaga pemasaran atau bagian marketing mengalami kesulitan memenuhi Peraturan perusahaan untuk melakukan kegiatan absen saat keluar dan masuk perusahaan.Tinggi nya aktifitas keluar masuk kantor mengakibatkan bagian marketing seringkali lupa melakukan absen.

Tujuan dari penelitian ini adalah merancang bangun sistem absensi dengan menggunakan teknologi Global Positioning System (GPS), sebagai solusi yang bermanfaat Pada PT. Cipta Anugrah Musi bagi bagian tenaga pemasaran untuk tetap dapat melakukan absensi tanpa menggunakan mesin absensi sidik jari.

\section{Tinjauan Literatur}

\subsection{Smartphone}

Smartphone adalah suatu mobile device yang tertanam sistem operasi sehingga memiliki kemampuan tingkat tinggi dan memiliki kemampuan menyerupai komputer (wikipedia.org). Smartphone adalah kombinasi antara telepon genggam, Personal Digital Assistant (PDA), media player, digital camera, dan Global Positioning System (GPS). Selain fitur-fitur tersebut, di dalam smartphone tertanam pula Bluetooth dan Wi-Fi serta kemampuan untuk mengakses internet dengan baik. Smartphone merupakan mobile device untuk masa depan yang menawarkan berbagai fungsi kemudahan dalam kemampuan nirkabel, daya komputasi, dan penyimpanan on-board. Sehingga secara tidak langsung smartphone memiliki kemampuan untuk mempermudah kegiatan manusia. Beberapa sistem operasi yang terdapat dalam smartphone adalah Symbian OS, iOS, Blackberry OS, Windows Mobile, Palm Os, Firefox OS, dan Android. Dengan kelebihan dan kekurangan yang dimiliki masing masing sistem operasi berbeda. (Rosyadi, 2016)

\subsection{Android}

Android adalah sebuah sistem operasi untuk perangkat mobile yang mencakup aplikasi sistem operasi, middleware dan aplikasi. Android SDK menyediakan fitur dan API yang diperlukan untuk mulai mengembangkan aplikasi pada platform Android dengan menggunakan bahasa pemrograman Java.

Android dikembangkan oleh Open Handset Alliance, Android membawa inovasi dengan internet dan keterbukaan terhadap perangkat mobile. Android memberikan sebuah software yang lengkap untuk aplikasi pada telepon seluler : sistem operasi, middleware dan aplikasi kunci dalam mobile.Arsitektur Android 


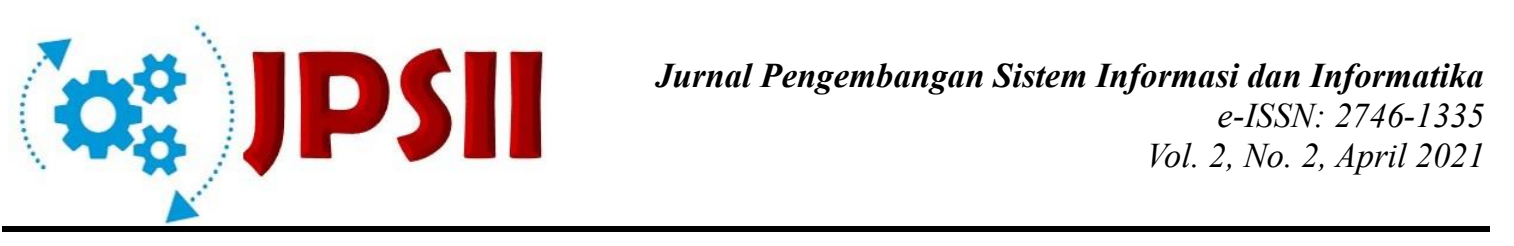

Android merupakan sekumpulan tumpukan software yang berjalan pada satu sistem yang terintegrasi dalam suatu device. Setiap satu lapisan menghimpun beberapa program untuk mendukung sistem-sistem spesifik dari sistem operasi.

\begin{tabular}{|c|c|c|c|c|}
\hline \multicolumn{5}{|c|}{ Applications and Widgets } \\
\hline Home & Contacts & Browser & Widgets & Your App Here \\
\hline \multicolumn{5}{|c|}{ Application Framework } \\
\hline $\begin{array}{l}\text { Activity } \\
\text { Manager }\end{array}$ & $\begin{array}{l}\text { Window } \\
\text { Manager }\end{array}$ & $\begin{array}{c}\text { Content } \\
\text { Providers }\end{array}$ & View System & $\begin{array}{l}\text { Notification } \\
\text { Manager }\end{array}$ \\
\hline $\begin{array}{l}\text { Package } \\
\text { Manager }\end{array}$ & $\begin{array}{l}\text { Telephony } \\
\text { Manager }\end{array}$ & Resource & $\begin{array}{l}\text { Location } \\
\text { Manager }\end{array}$ & $\begin{array}{l}\text { Sensor } \\
\text { Manager }\end{array}$ \\
\hline Libraries & & & \multicolumn{2}{|c|}{ Android Runtime } \\
\hline $\begin{array}{l}\text { Surface } \\
\text { Manager }\end{array}$ & $\begin{array}{c}\text { Media } \\
\text { Framework }\end{array}$ & SQLite & \multicolumn{2}{|c|}{ Core Libraries } \\
\hline OpenGL | ES & Freetype & Webkit & \multicolumn{2}{|c|}{$\begin{array}{l}\text { Dalvik Virtual } \\
\text { Machine }\end{array}$} \\
\hline SGL & SSL & libc & & \\
\hline \multicolumn{5}{|l|}{ Linux Kernel } \\
\hline Display Driver & $\begin{array}{l}\text { Bluetooth } \\
\text { Driver }\end{array}$ & Camera Driver & $\begin{array}{c}\text { Flash Memory } \\
\text { Driver }\end{array}$ & $\begin{array}{c}\text { Binder (IPC) } \\
\text { Driver }\end{array}$ \\
\hline Keypad Driver & USB Driver & WiFi Driver & Audio Drivers & $\begin{array}{c}\text { Power } \\
\text { Management }\end{array}$ \\
\hline
\end{tabular}

Gambar 2.1 Diagram Arsitektur Android

\section{Linux Kernel}

Tumpukan paling bawah dalam arsitektur Android adalah Kernel Linux. Kernel linux tidak pernah berinteraksi langsung dengan pengguna dan pengembang aplikasi, namun kernel menjadi bagian terpenting dari keseluruhan sistem yang bekerja. Seiring berkembangnya android, kernel linux juga mengalamai perkembangan pula. Berikut ini adalah tabel perbedaan versi android dan versi kernelnya.

\section{Libraries}

Lapisan berikutnya dalam arsitektur Android adalah Library. Library menerima seperangkat instruksi untuk memandu perangkat dalam menangani perbedaaan jenis data. Contohnya, playback dan recording adalah fitur dari format audio dan video yang dipandu oleh Media Framework Library.

Satu lapisan dengan library terdapat lapisan Android Runtime yang berisi librari-librari Java. Programer aplikasi Android membangun aplikasi mereka menggunakan bahasa pemrograman java disinilah letak library-library tersebut. Selain itu juga terdapat Dalvik Virtual Runtime, adalah software yang bertanggung jawab untuk semua aplikasi yang berjalan pada perangkat Android yang bersifat open-source.

\section{Application Framework}

Aplikasi Android secara langsung berinteraksi dengan lapisan ini dalam arsitektur Android. Program ini mengelola fungsi dasar telepon, seperti pengelolaan sumber daya, pengelolaan panggilan suara, dan lain-lain. Applications

Lapisan ini adalah lapisan paling tinggi dalam arsitektur Android. Secara umum, 
pengguna perangkat Android berinteraksi dengan lapisan ini. Seperti penggunaan fungsi dasar telepon, membuat panggilan telepon, mengakses mesin pencari, dan lain-lain. Selain pengguna, lapisan ini juga digunakan oleh banyak pengembang dan programmer.

\section{Android Software DevelopmentKit(SDK)}

Android Software Development Kit(SDK) adalah suatu program aplikasi yang disediakan google secara resmi yang menyediakan API libraries dan kebutuhan developer tools untuk membangun, menguji, dan men-debug aplikasi Android.

\subsection{Android DeveloperTool(ADT)}

Android Developer Tool(ADT) adalah plugin yang menyediakan perangkat- perangkat untuk pengembangan aplikasi Android yang ter-integrasi dengan Eclipse IDE. ADT memiliki keungulan dalam peng-aksesan GUI(Graphical User Interface) sehingga pengembang aplikasi dapat dengan mudah membuat prototipe, melakukan, dan membangun antar muka aplikasi.

\subsection{Location BasedService(LBS)}

Location Based Service (LBS) adalah layanan mobile yang memiliki kemampuan untuk menyediakan informasi secara real-time berdasar lokasi pengguna. LBS saat ini banyak digunakan diberbagai media sosial sebagai layanan hiburan. Dengan kemudahan dalam pengaksesan perangkat mobile terutama mobile network dengan menggunakan posisi geografis dari perangkat mobile. Fitur ini disebut geo-tagging.

Geographic Information System(GIS) adalah jantung dari Location Based Service(LBS) dalam menyediakan semua fungsi dalam LBS (Priyanka, 2017). Pertama kita mungkin mengirimkan informasi lokasi pada bagian kontrol. Pada bagian ini menyediakan layanan yang biasa digunakan seperti pada aplikasi tracking lokasi. Kedua, menggunakan informasi lokasi untuk membuat keputusan dalam komunikasi, seperti user yang menonaktifkan aplikasi instant messaging ketika mengendara secara otomatis. Mengirim informasi lokasi untuk mengontrol dalam men-tracking lokasi biasanya mewakili koordinat geospasial atau men- tracking alamat penduduk.

\subsection{Web Server}

Web server merupakan sebuah proses yang berjalan pada komputer host, yang menunggu request dari HTTP masuk. Web server menyediakan akses terhadap informasi dan layanan yang di simpan dalam web. Eaglestonedan Menurut Hoffer, Prescott, dan Topi (2009, p469), web server digunakan untuk memproses permintaan dari klien dan kemudian mengembalikan halaman HTML kepada klien.

\subsection{PHP}

PHP adalah bahasa script di sisi server yang didesain secara khusus untuk jaringan. Dalam halaman HTML, bisa dimasukan kode PHP yang akan dieksekusi tiap kali halaman di kunjungi. Kode PHP akan di terjemahkan di jaringan server dan mengenerate HTML atau output lain yang dilihat oleh pengunjung. Secara khusus, PHP di rancang untuk membentuk web dinamis. Artinya ia dapat membentuk suatu tampilan berdasarkan permintaan terkini. Misalnya, anda dapat menampilkan isi database ke halaman Web. Pada prinsipnya, PHP mempunyai fungsi yang sama dengan skrip-skrip seperti ASP (Active Server Page), Cold Fusion ataupun Perl.Kelahiran PHP bermula saat Ramus 
Lerdorf membuat sejumlah skrip Perl yang dapat mengamati siapa saja yang melihat-lihat daftar riwayat hidupnya, pada tahun 1994. Skrip-skrip ini selanjutnya dikemas menjadi tool yang disebut "Personal Home Page". Paket inilah yang menjadi cikal-bakal PHP. Pada tahun 1995, Rasmus menciptakan PHP/FI Versi 2. Pada versi inilah pemrograman dapat menempelkan kode terstruktur di dalam tag HTML. Yang menarik, kode PHP juga bisa berkomunikasi dengan database dan melakukan perhitungan-perhitungan yang kompleks sambil jalan.

Pada saat ini, PHP cukup populer sebagai piranti pemrograman Web, terutama di lingkungan Linux. Walaupun demikian, PHP sebenernya jugadapat berfungsi pada serverserver yang berbasi UNIX, Windows NT, dan Macintosh. Bahkan versi untuk Windows 95/98 juga tersedia.Menurut dokumen resmi PHP, PHP singkatan dari PHP Hypertext Preprocessor. PHP merupakan bahasa berbentuk skrip yang di tempatkan dalam server dan diproses di server. Hasilnya yang di kirimkan ke klien, tempat pemakai menggunakan browser.Pada awalnya, PHP di rancang untuk diintegrasikan dengan Web server Apache. Namun, belakangan ini PHP juga dapat bekerja dengan Web server seperti PWS (Personal Web Server), IIS (Internet Information Server), dan Xitami. Untuk mencoba PHP, anda tidak perlu menggunakan komputer berkelas server. Dengan hanya komputer biasa, anda bisa mempelajari dan mempraktekan PHP.

\subsection{MySQL}

MySQL adalah database server relasional yang gratis di bawah lisensi GNU General Public License. Dengan sifatnya yang Open Source, memungkinkan user juga untuk melakukan modifikasi pada source code-nya untuk memenuhi kebutuhan spesifik mereka sendiri. MySQL merupakan database server multi-user dan multi-threded yang tangguh (robust). Dengan memiliki banyak feature MySQL bias bersaing dengan database komersial sekalipun. Tidak mengejutkan, MySQL menjadi database pilihan untuk banyak pengguna PHP. MySQL dikembangkan oleh MySQL AB, sebuah perusahaan komersial yang membangun layanan bisnisnya melalui database MySQL. Awal mula pengembangan MySQL adalah penggunaan mySQL untuk koneksi ke table mempergunakan rutin level rendah (ISAM) setelah beberapa pengujian diperoleh kesimpulan $\mathrm{mSQL}$ tidak cukup cepat dan fleksibel untuk memenuhi kebutuhan. Sehingga dihasilkan suatu antarmuka SQL baru pada database tetapi dengan API yang mirip mSQL. API ini dipilih sedemikian rupa sehingga memudahkan porting kode. Tentang penggunaan nama MySQL sampai saat ini belum jelas betul. Base directory dan sejumlah library serta tool pada saat pengembangan telah diawali dengan "my" selama sekitar 10 tahun. Bagaimanapun pemberian nama MySQL sampai saat ini masih menjadi sebuah "misteri". MySQL adalah suatu sistem manajemen database.Untuk menambahkan,mengakses, dan memproses data yang tersimpan pada suatudatabase computer anda memerlukan sistem manajemen database seperti MySQL. Karena computer sangat unggul dalam menangani sejumlah besar data, system manajemen database memainkan suatu peranan yang peting dalam komputansi, baik sebagai utility stand-alone maupun bagian dari aplikasi lainnya.

MySQL adalah system manajemen database relasional. Suatu database relasional menyimpan data dalam table-tabel terpisah. Hal ini memungkin kecepatan dan fleksibelitas. Table-tabel yang dihubunkan dengan relasi yang ditentukan membuatnya bias mengkombinasikan data dari beberapa table pada suatu permintaan. Bagian SQL dari 
kata MySQL berasal dari "Structured Query Language" bahasa paling umum yang dipergunakan untuk mengakses database. Konektivitas, kecepatan dan keamanannya membuat MySQL cocok untuk pengaksesan database pada internet. MySQL merupakan sistem client/server yang terdiri dari SQL server multi heraded yang memungkinkan backed yang berbeda, sejumlah program client dan library yang berbeda, tool administrative, dan beberapa antarmuka pemrograman. MySQL juga tersedia sebagai library yang bisa digabungkan keaplikasi.

\subsection{SQLite}

SQLite itu merupakan sebuah Database yang bersifat ACID-compliant dan memiliki ukuran pustaka kode yang relatif kecil, ditulis dalam bahasa C. SQLite merupakan proyek yang bersifat public domain yang dikerjakan oleh D. Richard Hipp. SQLite adalah sebuah open source database yang telah ada cukup lama, cukup stabil, dan sangat terkenal pada perangkat kecil, termasuk Android. Android menyediakan database relasional yang ringan untuk setiap aplikasi menggunakan SQLite. Aplikasi dapat mengambil keuntungan dari itu untuk mengatur relational database engine untuk menyimpan data secara aman dan efiesien. Untuk Android, SQLite dijadikan satu di dalam Android runtime, sehingga setiap aplikasi Android dapat membuat basis data SQLite. Karena SQLite menggunakan antarmuka SQL, cukup mudah untuk digunakan orang orang dengan pengalaman lain yang berbasis databases. Terdapat beberapa alasan mengapa SQLite sangat cocok untuk pengembangan aplikasi Android, yaitu:

Database dengan konfigurasi nol. Artinya tidak ada konfigurasi database untuk para developer. Ini membuatnya relatif mudah digunakan. Tidak memiliki server. Tidak ada proses database SQLite yang berjalan. Pada dasarnya satu set libraries menyediakan fungsionalitas database. Single-file database. Ini membuat keamanan database secara langsung. Open source. Hal ini membuat developer mudah dalam pengembangan aplikasi.

\subsection{Fitur-fiturSQLite}

Pustaka SQLite mengimplementasikan hampir seluruh elemen-elemen standar yang berlaku pada SQL-92, termasuk transaksi yang bersifat atomic, konsistensi basis data, isolasi, dan durabilitas (dalam bahasa inggris lebih sering disebut ACID), trigger, dan kueri-kueri yang kompleks. Tidak ada pengecekan tipe sehingga data bisa dientrikan dalam bentuk string untuk sebuah kolom bertipe integer. Beberapa kalangan melihat hal ini sebagai sebuah inovasi yang menambah nilai guna dari sebuah basisdata, utamanya ketika digunakan dalam bahasa pemrograman berbasis script (PHP, Perl), sementara kalangan lain melihat hal tersebut sebagai sebuah kekurangan.Beberapa proses ataupun thread dapat berjalan secara bersamaan dan mengakses basis data yang sama tanpa mengalami masalah. Hal ini disebabkan karena akes baca data dilakukan secara paralel. Sementara itu akses tulis data hanya bisa dilakukan jika tidak ada proses tulis lain yang sedang dilakukan; jika tidak, proses tulis tersebut akan gagal dan mengembalikan kode kesalahan (atau bisa juga secara otomatis akan mencobanya kembali sampai sejumlah nilai waktu yang ditentukan habis). Hanya saja ketika sebuah tabel temporer dibuat, mekanisme penguncian pada proses multithread akan menyebabkan masalah. Update yang terkini (versi 3.3.4) dikatakan telah memperbaiki masalah ini. Sebuah program yang mandiri dinamakan sqlite disediakan dan bisa digunakan untuk mengeksekusi kueri dan memanajemen file-filebasis data SQLite. Program tersebut juga merupakan contoh 


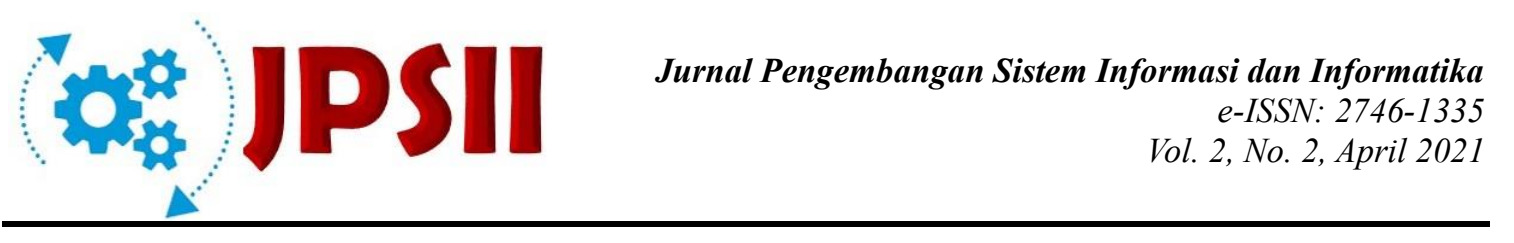

implementasi penulisan aplikasi yang menggunakan pustaka SQLite.

\section{Metode Penelitian}

\subsection{Komunikasi}

Komunikasi merupakan tahapan awal dalam perancangan sistem untuk mengidentifikasi masalah dan kebutuhan-kebutuhan dalam pembangunan sebuah sistem, agar diperoleh hasil yang maksimal dan keakuratan aplikasi dalam proses presensi yang berjalan. Dari komunikasi peneliti dengan staff PT. Cipta Anugrah Musi penerapan sistem manual dalam proses presensi memiliki beberapa kelemahan . Kelemahan tersebut diantaranya adalah data presensi tidak dapat dilakukan pembuktian dan dapat terjadi kecurangan dalam proses pencatatan data presensi pada jam masuk kerja, penyimpanan data presensi karyawan di tempatkan pada tumpukan arsip yang selanjutnya akan ditempatkan di gudang sehingga rentan terjadinya kehilangan data, pencarian data dan informasi mengenai karyawan dilakukan secara manual, proses pembuatan laporan presensi membutuhkan waktu yang lama karena proses pembuatan laporan presensi dikerjaan oleh bagian administrasi yang hanya terdiri atas satu orang.

Dari hasil analisa diatas dibuat suatu sistem untuk permasalahan seputar presensi karyawan, dimana karyawan cukup menjalankan aplikasi kemudian melakukan melakukan absen dengan pengambilan foto selfie gambar muka maka hasil akan langsung masuk ke dalam sistem dan dapat dilihat admin secara real time, dalam pengambilan foto gambar pada aplikasi akan langsung menjalankan atau mengaktifkan GPS Location, ini digunakan agar fungsi Geotagging akan aktif jadi pada saat gambar diambil maka gambar tersebut akan menyimpan lokasi kordinat secara otomatis, dengan begini admin akan mengetahui lokasi sumber absensi karyawan saat karyawan mengambil foto sehingga tidak akan terjadi kecurangan dalam melakukan absensi.

\subsection{Perencanaan}

Berdasarkan komunikasi maka dibuatlah suatu perencanaan pada pembangunan sistem monitoring presensi karyawan diawali dengan menjelaskan mengenai data masukkan dan data keluaran, serta perangkat keras dan perangkat lunak yang akan dibutuhkan dalam pembangunan sistem.

\subsubsection{Data}

Data merupakan informasi baik berupa teks, gambar, maupun video. Data dalam sistem monitoring presensi karyawan pemasaran berbasis android dengan memanfaatkan GPS digunakan dalam dua kebutuhan yaitu:

1. Kebutuhan Data Masukkan

Kebutuhan data masukkan pada sistem ini dibedakan menjadi dua, yaitu:

a) Data yang dimasukkan oleh Karyawan terdiri dari data absensi berupa foto selfie karyawan.

b) Data yang dimasukkan oleh Admin yaitu login sistem, hasil aporan presensi karyawan.

2. Kebutuhan Data Keluaran

Kebutuhan data keluaran dari sistem ini adalah informasi berupa laporan presensi karyawan. 


\subsubsection{Kebutuhan Perangkat Keras}

Spesifikasi perangkat keras yang digunakan pada saat pembangunan sistem monitoring presensi karyawan pemasaran berbasis android dengan memanfaatkan GPS yaitu:
a. Processor AMD E1
b. 2 GB Memory DDR 3
c. Harddisk 500 GB HDD

\subsubsection{Kebutuhan Perangkat Lunak}

Perangkat lunak yang dibutuhkan dalam pembangunan sistem monitoring presensi karyawan pemasaran berbasis android dengan memanfaatkan GPS ini yaitu:
a. Windows 10 Professional
b. Eclipse
c. ADTTools
d. $\quad X A M P P$, terdiri atas Apache, MySQL, dan phpMyAdmin
e. $\quad$ Macromedia Dreamweaver CS6
f. Mozila Firefox

\subsection{Pemodelan}

Setelah tahap perencanaan selanjutnya akan dilakukan pemodelan sistem yang akan di implementasikan menggunakan bahasa pemrograman java, php untuk DBMS menggunakan MySQL serta Eclipse dan Dreamweaver CS6 digunakan sebagai tempat membuat layout sistem yang akan dirancang.

Pemodelan sistem merupakan awal dari pembuatan sistem yang akan dibuat, dimana dapat dilihat proses-proses apa saja yang nantinya diperlukan dalam pembuatan suatu sistem, berikut usulan sistem yang akan dibuat menggunakan pemodelan Unified Modelling Language (UML).

\subsubsection{Unified Modeling Language (UML)}

Perancangan sistem mengunakan permodelan berorientasi objek Unified Modeling Language (UML), yaitu Use Case Diagram, Activity Diagram dan Class Diagram.

\subsubsection{Usecase Diagram}

Use case diagram merupakan diagram yang menggambarkan semua kasus (case) yang akan ditangani oleh perangkat lunak beserta aktor atau pelakunya. Rancangan sistem yang diimplementasikan dalam bentuk diagram UML (Unified Modeling Language). Diagram Use Case untuk penerapan aplikasi ini terdapat 2 aktor yaitu Admin dan Karyawan, yang memiliki fungsi berbeda-beda. Dapat dilihat pada Gambar 3.1. 

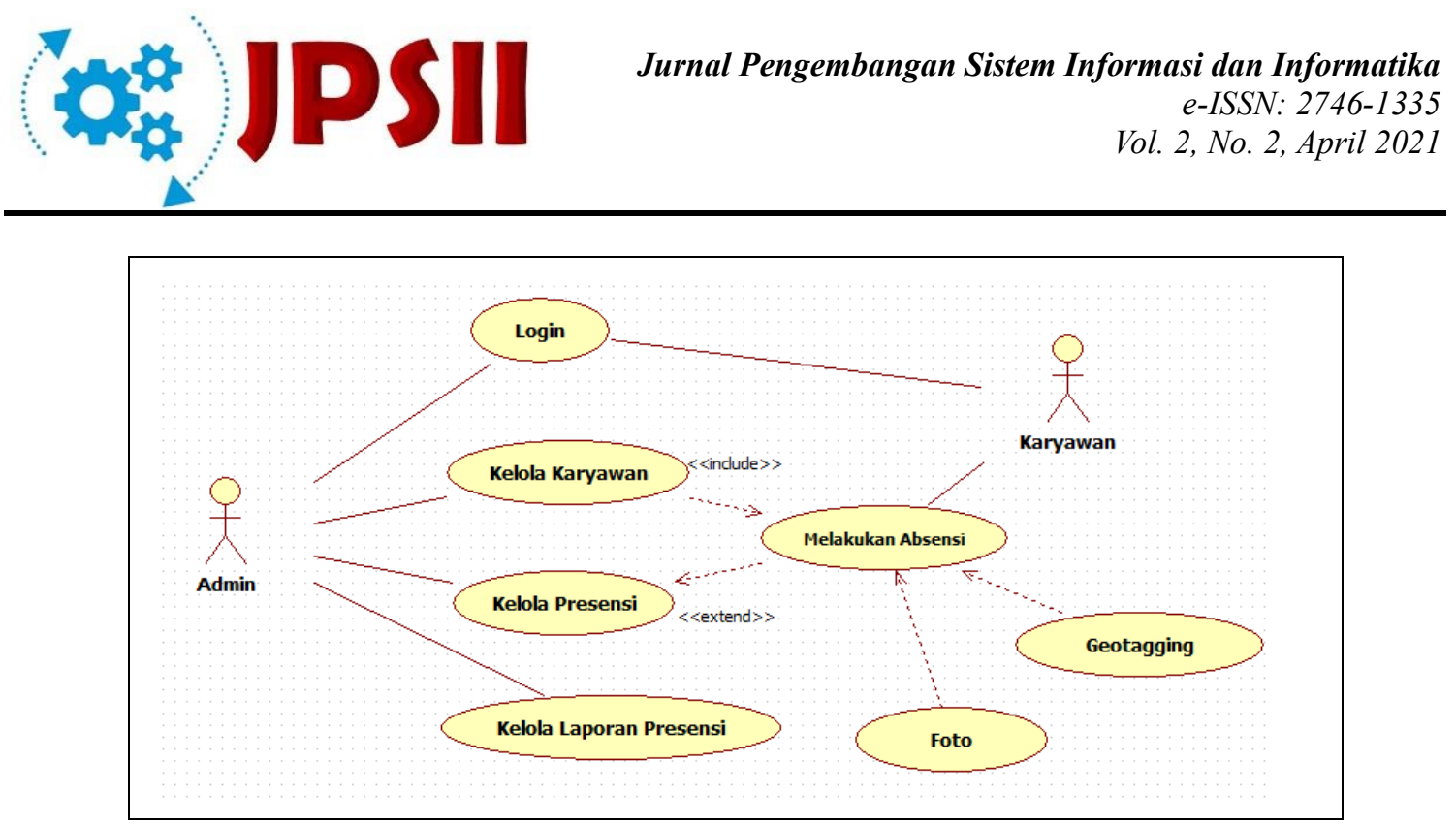

Gambar 3.1 Usecase Diagram

\subsubsection{Activity Diagram}

Activity Diagram meliputi Activity Diagram Admin, dan Activity Diagram Karyawan. Acitivty Diagram dapat menunjukkan aktivitas-aktivitas yang dilakukan oleh aktor dengan digambarkan aktivitasnya. Untuk Activity Diagram Admin dapat dilihat pada Gambar 3.2, dan untuk Activity Diagram Karyawan dapat dilihat pada Gambar 3.3.

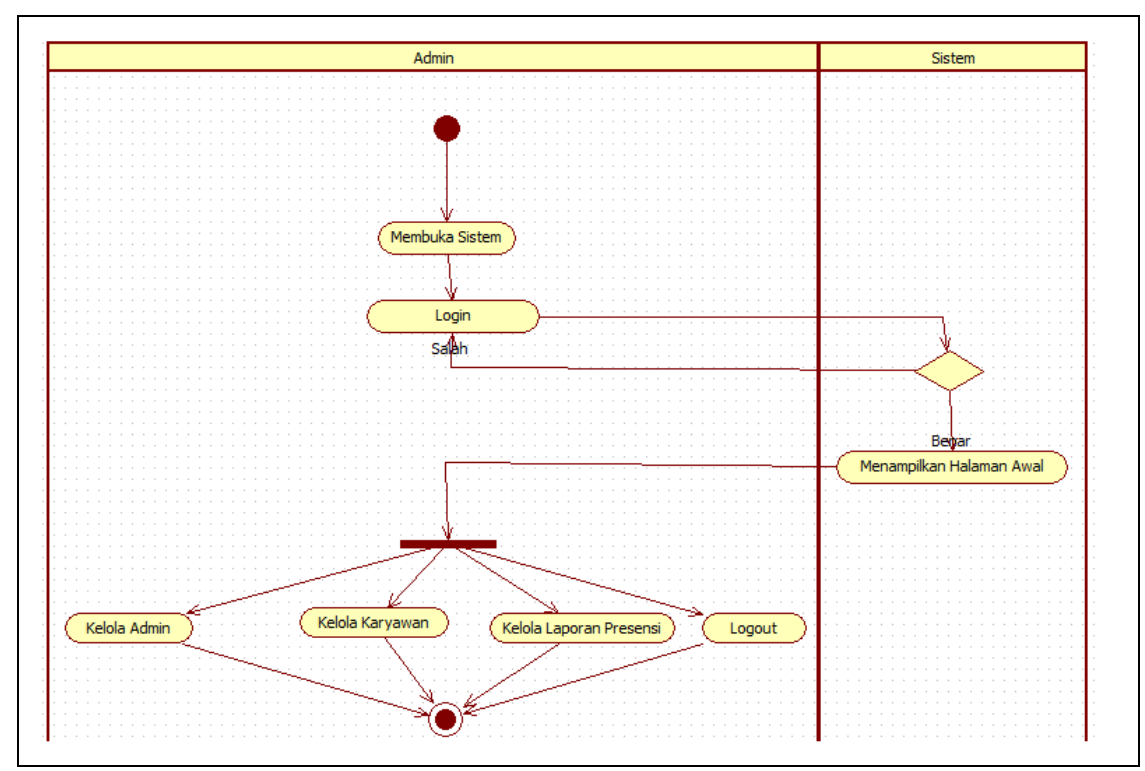

Gambar 3.2 Activity Diagram Admin

Dari activity diagram diatas dapat diketahui bahwa aktifitas aktor Admin hanya dapat mengelola data admin, data karyawan, dan laporan presensi. 


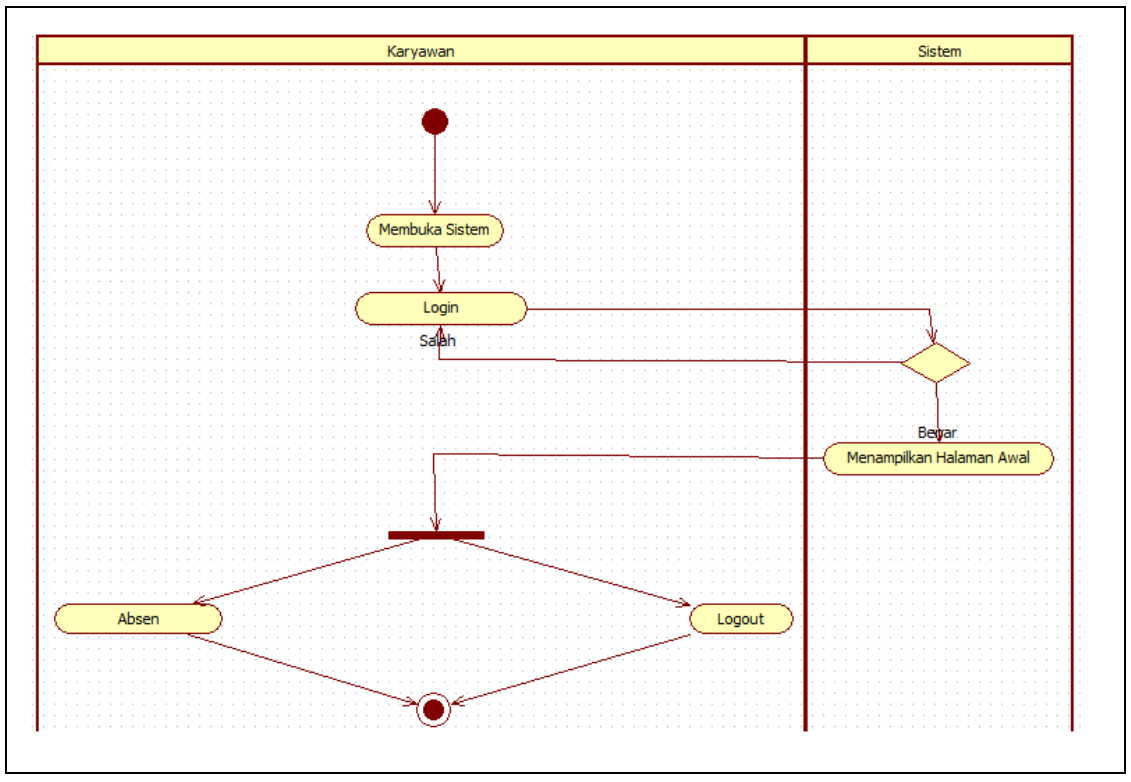

Gambar 3.3 Activity Diagram Karyawan

\section{Hasil dan Pembahasan}

\subsection{Hasil}

Hasil yang didapatkan dari pembuatan sistem ini adalah adanya sistem monitoring presensi karyawan pemasaran dalam bentuk mobile android dengan memanfaat GPS. Pada sistem ini memiliki 2 pengguna yang berhak mengakses sistem yaitu Admin dan Karyawan. Setiap pengguna memiliki hak akses masing-masing dan setiap hak akses dibuat dengan disesuaikan kebutuhan pengguna..

\subsubsection{Skema Alur Kerja Sistem}

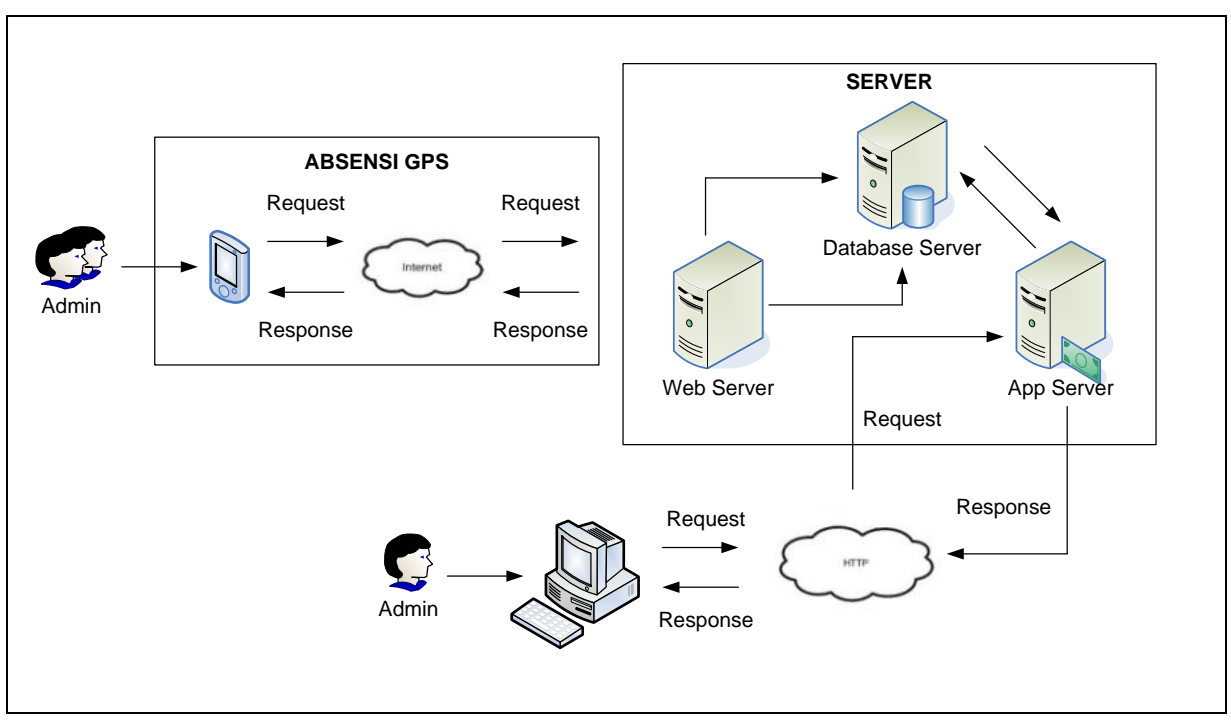

Gambar 4.1 Sekma alur kerja sistem yang diusulkan

Gambar diatas merupakan gambaran dari alur kerja sistem aplikasi yang akan diusulkan, pada gambar diatas dijelaskan bahwa terdapat 2 aktor yaitu Karyawan dan Admin. Pada karyawan akan melakukan permintaan absensi berupa foto selfie yang akan langsung 
mengirimkan titik kordinat ke dalam sistem, kemudian pada bagian Admin dapat melakukan cek absensi karawan lengkap dengan titik koordinat karywan pada saat absensi secara otomatis langsung bisa direkap. Dari aksi yag dilakukan karyawan dan admin akan terhubung melalui media internet dan alamat server hosting, kemudian data disimpan ke dalam Server berbasis online untuk saling berkomunikasi antar karyawan dan admin.

\subsection{Pembahasan}

Pada bab ini akan dijelaskan apa saja proses-proses yang terjadi dan bagaimana sistem yang telah dibuat akan berjalan nantinya. sistem monitoring presensi karyawan pemasaran dalam bentuk mobile android ini akan dapat membantu beberapa pekerjaan khususnya admin sebagai pengguna dalam memonitoring presensi karyawan. Pembahasan sistem dilakukan oleh 2 pengguna yaitu Admin dan Karyawan yang memiliki fungsi masing-masing.

\subsubsection{Antarmuka Bagi Admin (Web)}

\section{Halaman Login (Admin)}

Halaman Login merupakan Halaman awal yang tampil saat pengguna (user) masuk kedalam sistem. Login sistem menggunakan username dan password yang disesuaikan dengan pengguna. Berikut adalah Halaman Login Pengguna terlihat Pada Gambar 4.2:

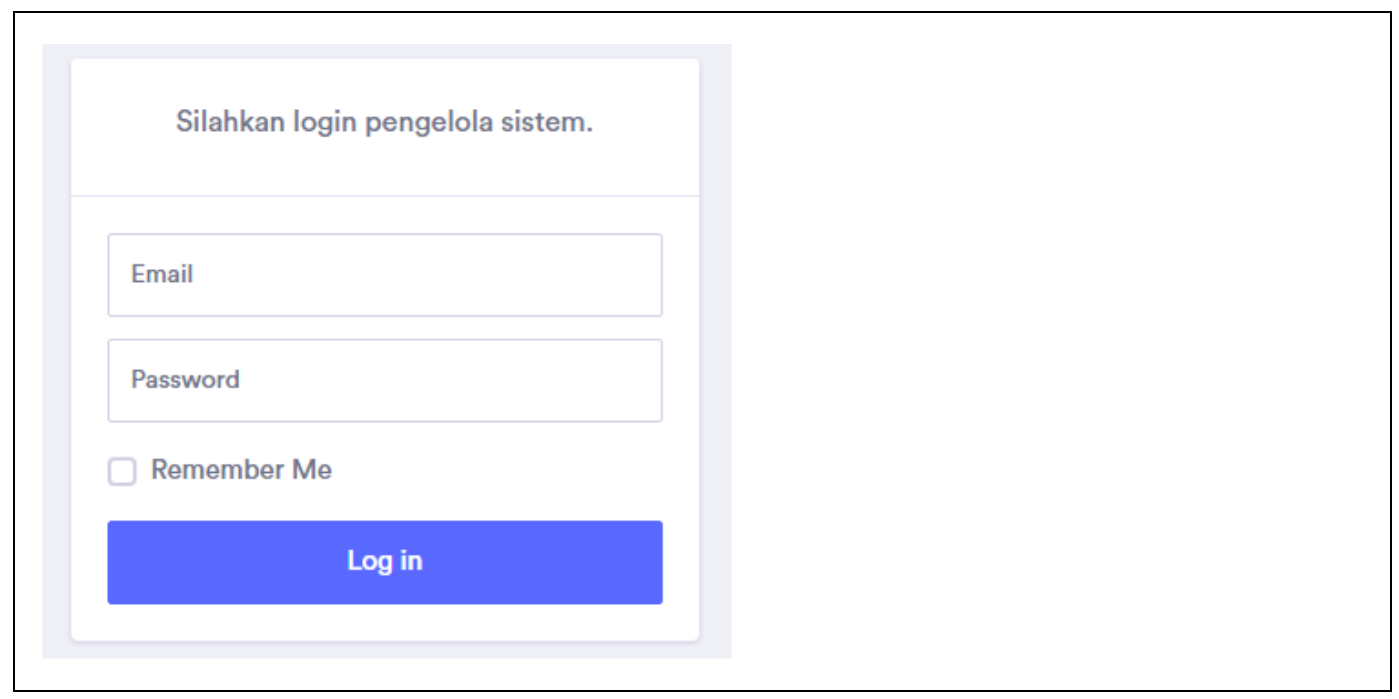

Gambar 4.2 Halaman Login Admin dan Pimpinan

2. Halaman Dashboard (Admin)

Halaman dashboard merupakan halaman yang digunakan untuk menampilkan atau masuk ke halaman lain yang bisa di akses administrator. Untuk halaman dashboard dapat dilihat pada Gambar 4.3 

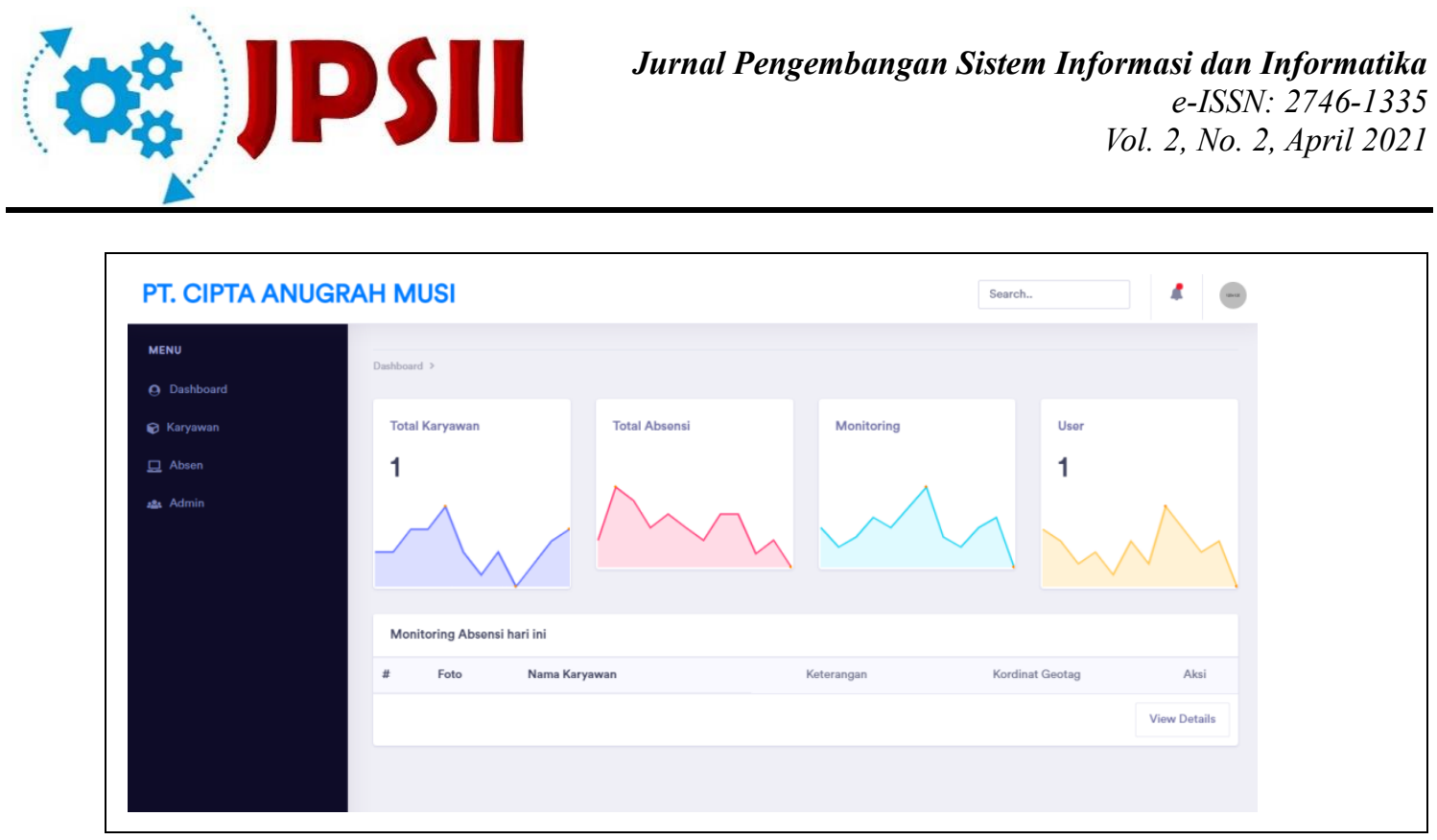

Gambar 4.3 Halaman Dashboard Admin

3. Tampil Halaman Monitoring Absen (Admin)

Halaman monitoring merupakan halaman yang digunakan untuk menampilkan data presensi karyawan melalui mobile yang akan tampil secara otomatis. Berikut tampilan halaman monitoring terlihat pada Gambar 4.4.

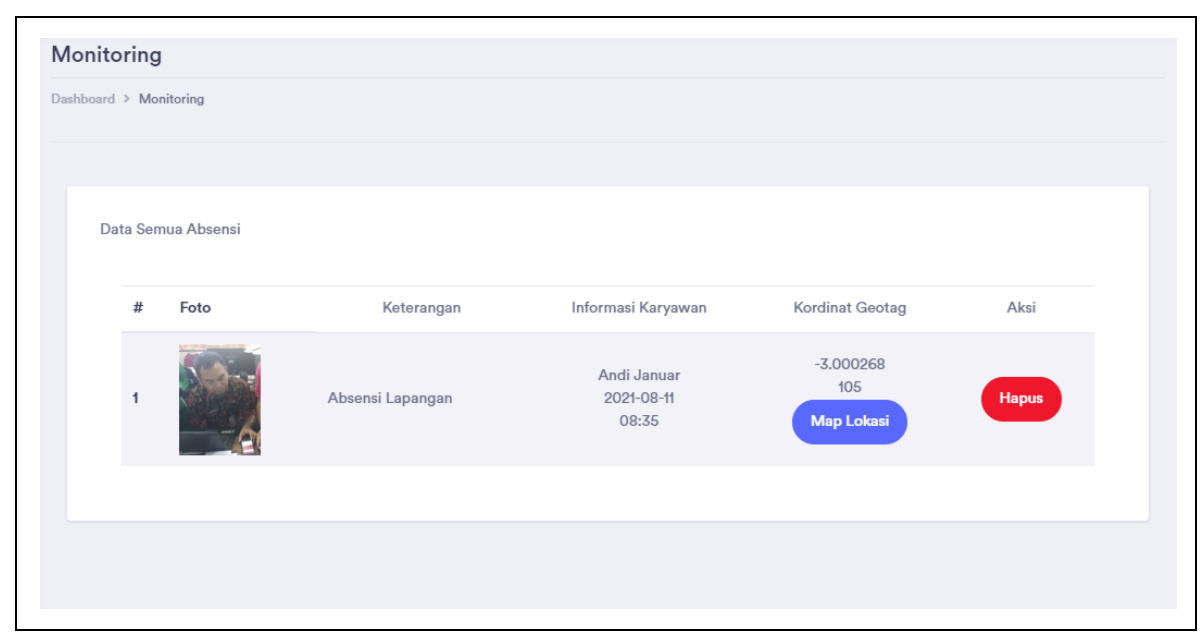

Gambar 4.4 Halaman Monitoring Absen

\section{Tampil Halaman Geotagging Absen (Admin)}

Halaman geotagging merupakan halaman untuk menunjukkan hasil dari foto geotag yang diambil dari petugas monitoring secara langsung. foto tersebut memiliki koordinat longitude dan latitude yang secara langsung akan mengarahkan ke satelit map yang akan menunjukkan tempat dari gambar yang diambil lokasinya dan juga memiliki data dari foto tersebut. Berikut tampilan halaman geotagging yang terlihat pada $\mathrm{G}$ 

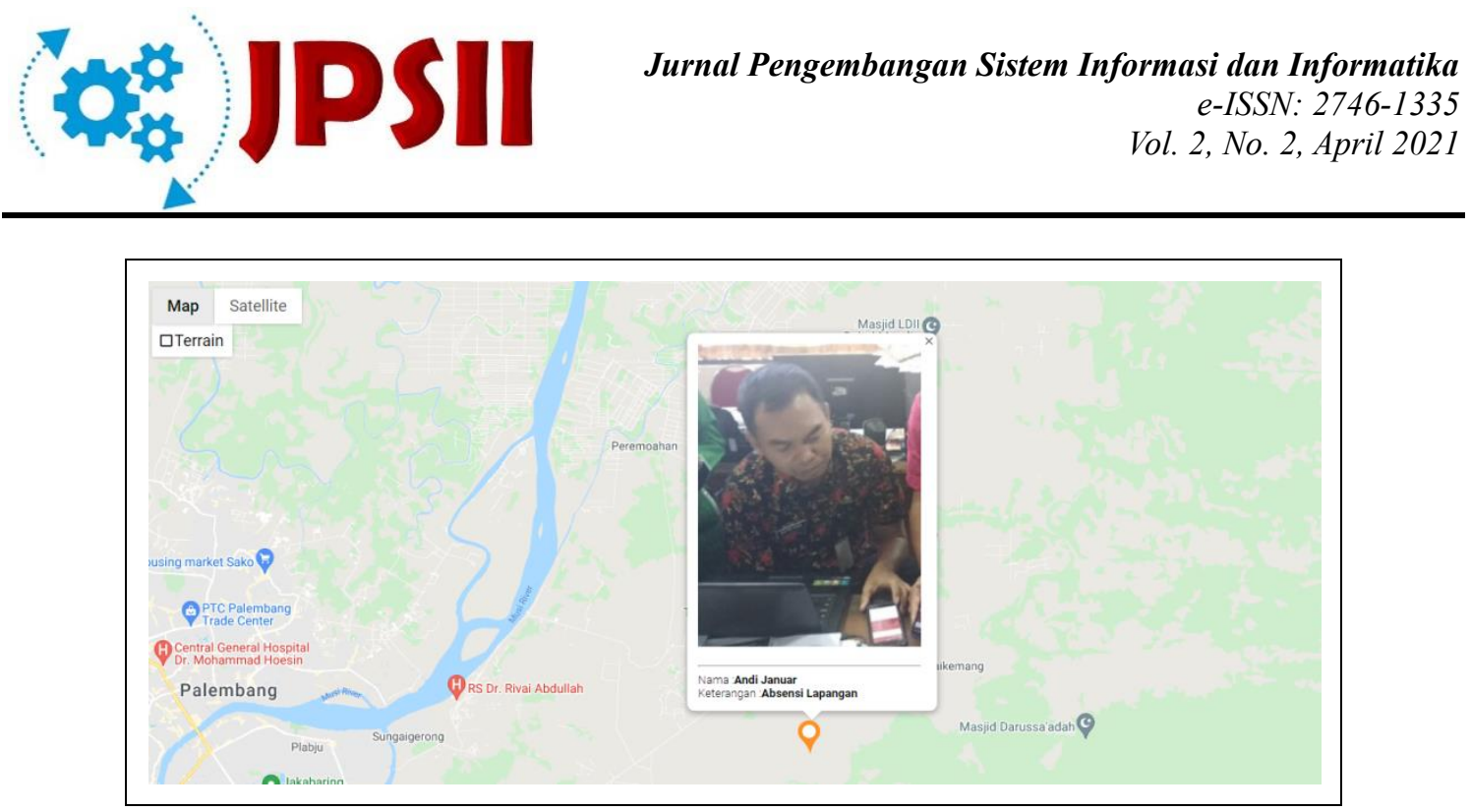

Gambar 4.5 Halaman Geotagging

5. Tampil Pengguna (Admin)

Halaman pengguna merupakan halaman yang digunakan untuk menampilkan data pengguna yang berhak menjalankan aplikasi.Berikut tampilan halaman pengguna terlihat pada Gambar 4.6.

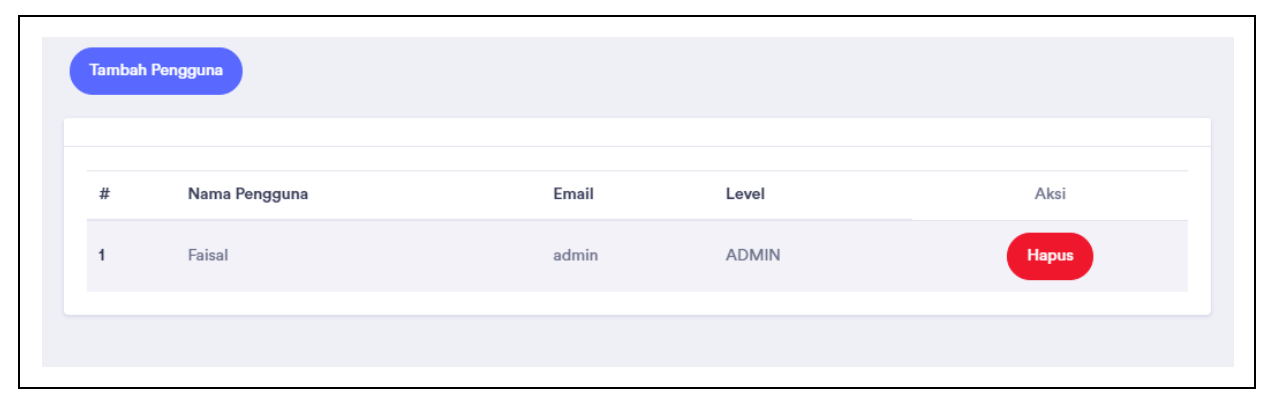

Gambar 4.6 Halaman Pengguna Admin

Jika diklik tombol tambah pengguna maka akan tampil form untuk menambahkan data pengguna yang berhak menjalankan aplikasi. Berikut tampilan halaman tambah pengguna terlihat pada Gambar 4.7.

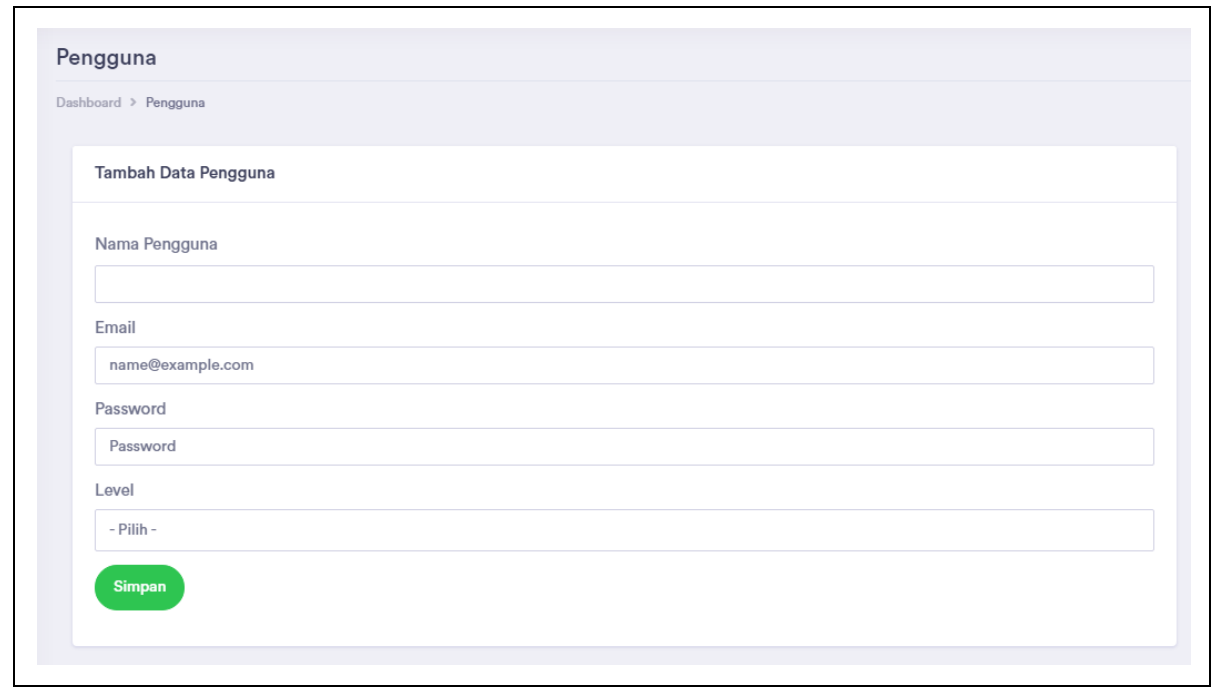

Gambar 4.7 Halaman Tambah Pengguna Admin

Published by: 
6. Tampil Halaman Akun Saya (Admin)

Halaman akun saya merupakan halaman yang digunakan untuk pengguna jika ingin mengubah data informasi pengguna seperti nama dan username.Berikut tampilan halaman akun saya terlihat pada Gambar 4.8.

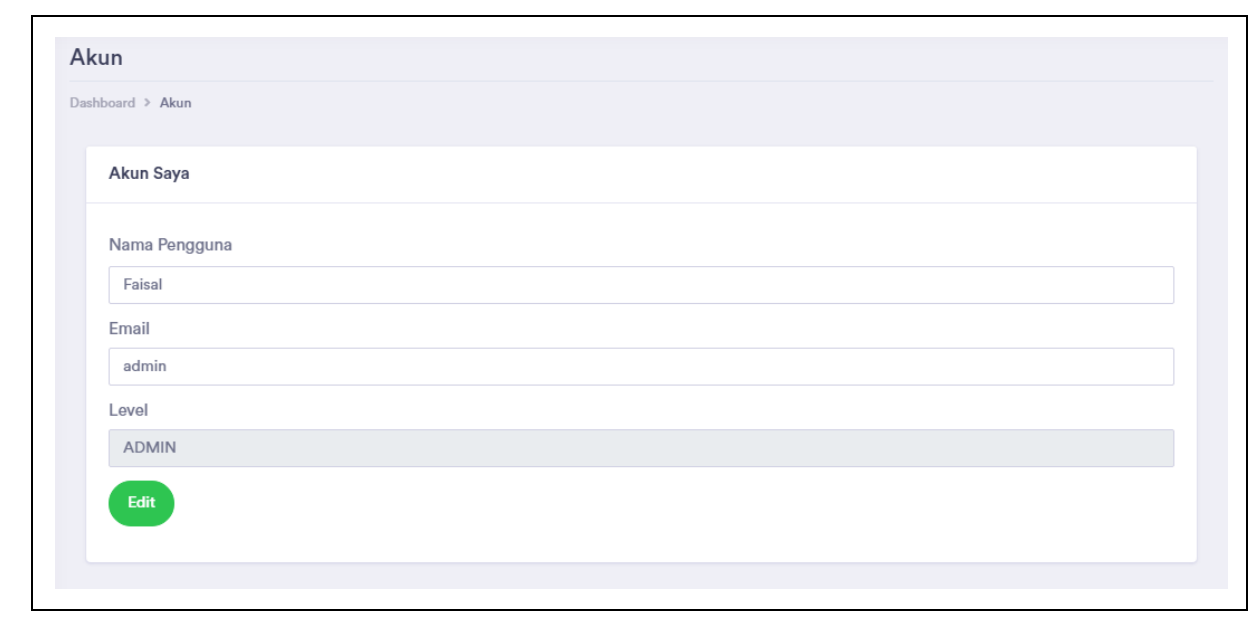

Gambar 4.8 Halaman Akun Saya Admin

7. Tampil Halaman Ubah Password (Admin)

Halaman ubah password merupakan halaman yang digunakan untuk pengguna jika ingin mengubah password. Berikut tampilan halaman ubah password terlihat pada Gambar 4.9.

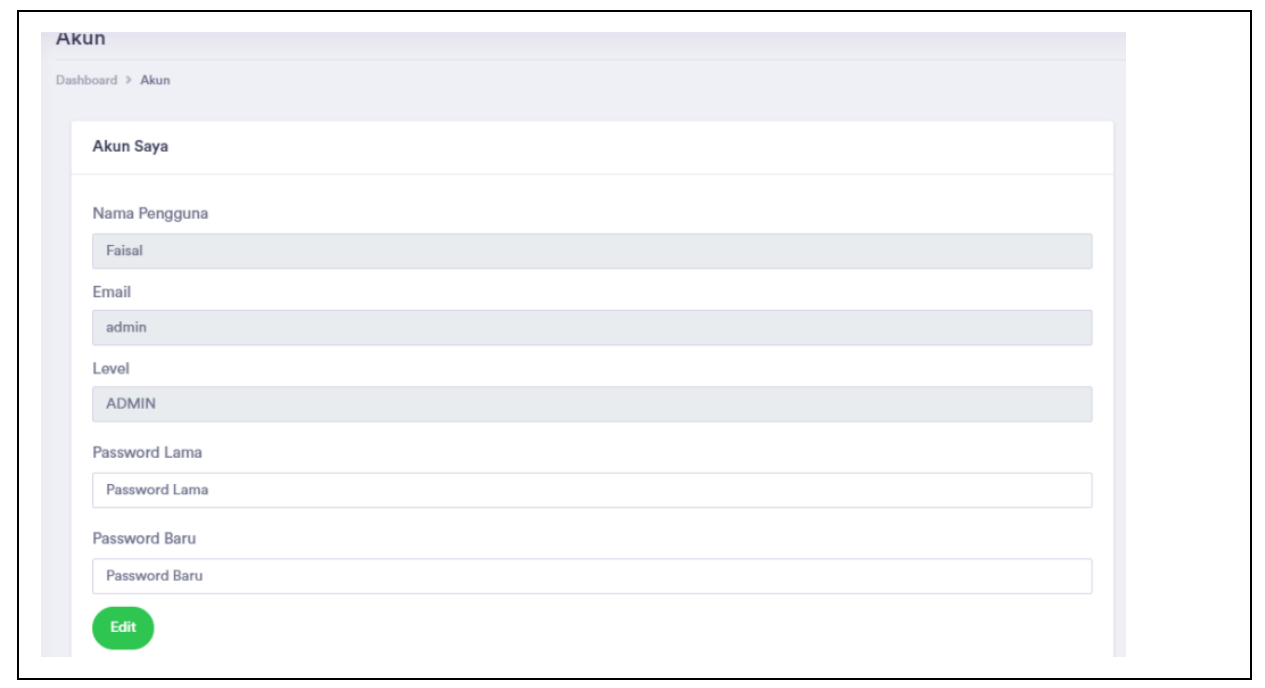

Gambar 4.9 Halaman Ubah Password Admin

8. Tampil Halaman Karyawan (Admin)

Halaman karyawan merupakan halaman yang digunakan untuk menampilkan dan menambahkan data karyawan yang terdaftar di PT. Cipta Anugrah Musi pada setiap bulan dan tahunnya. Berikut tampilan halaman karyawan terlihat pada Gambar 4.10. 


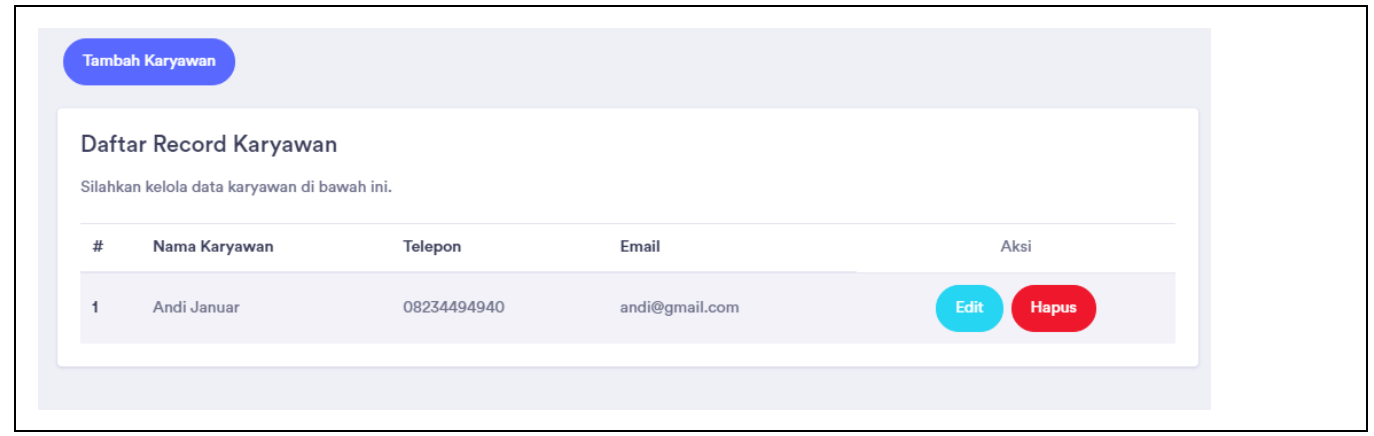

Gambar 4.10 Halaman Karyawan

Jika diklik tombol tambah maka akan tampil form untuk menambahkan data karyawan. Berikut tampilan halaman tambah flora dan fauna terlihat pada Gambar 4.11.

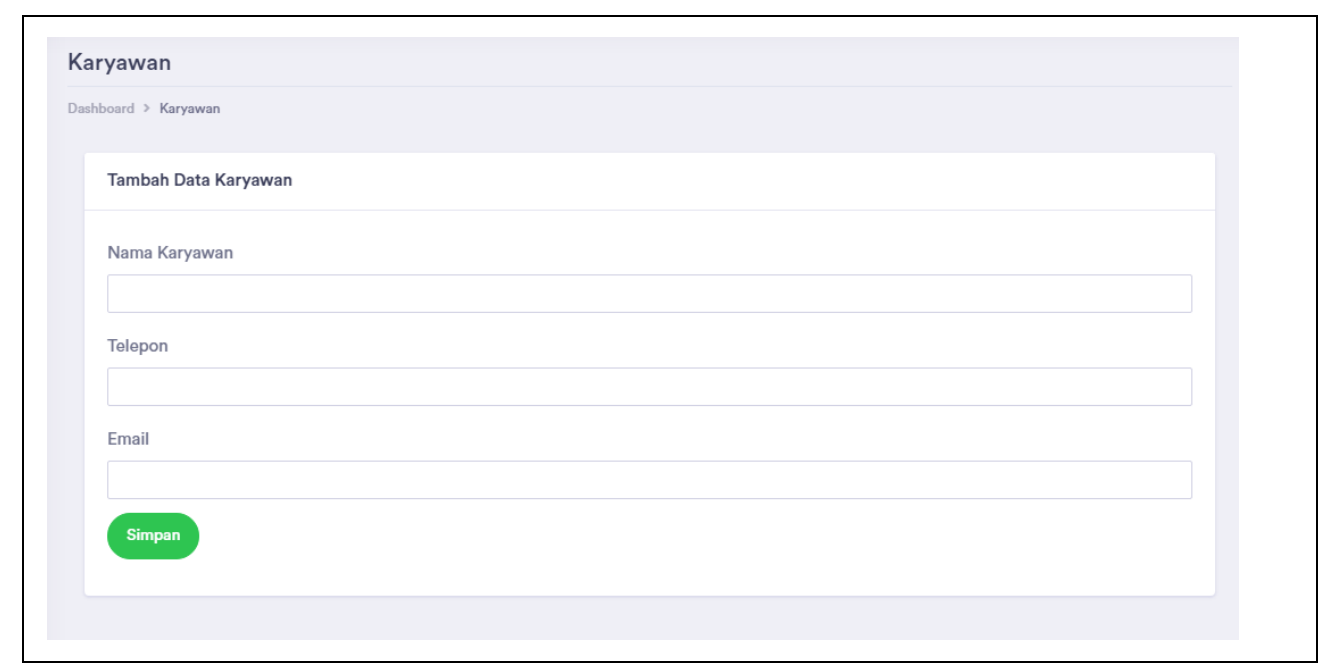

Gambar 4.11 Halaman Tambah Karyawan

\subsubsection{Antarmuka Bagi Karyawan (Android)}

\section{Halaman Login}

Halaman login merupakan halaman yang bisa digunakan petugas monitoring untuk login kedalam sistem. Untuk halaman Login dapat dilihat pada Gambar 4.12. 


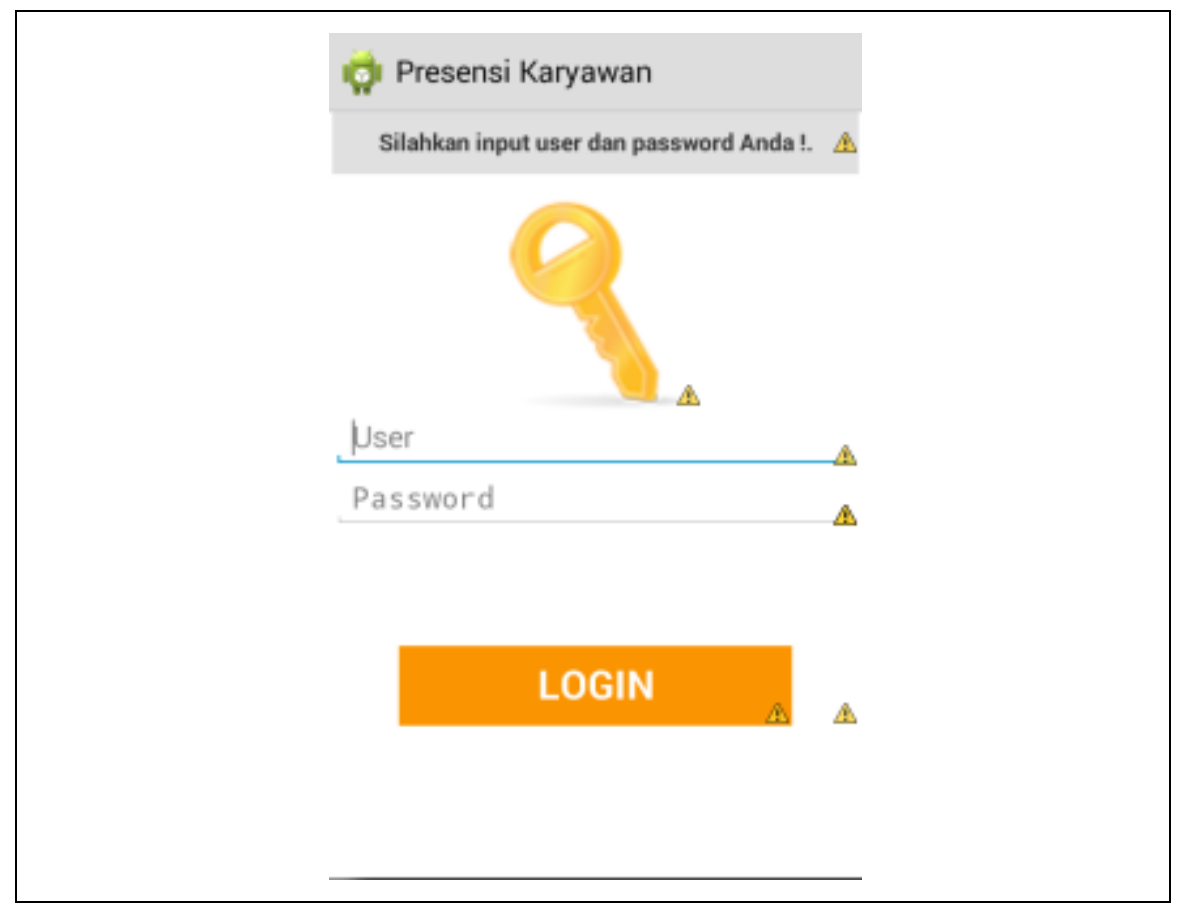

Gambar 4.12 Halaman Login

2. Halaman Absen

Halaman absen merupakan halaman yang akan menampilkan menu absensi karyawan. Untuk halaman absen dapat dilihat pada Gambar 4.13.

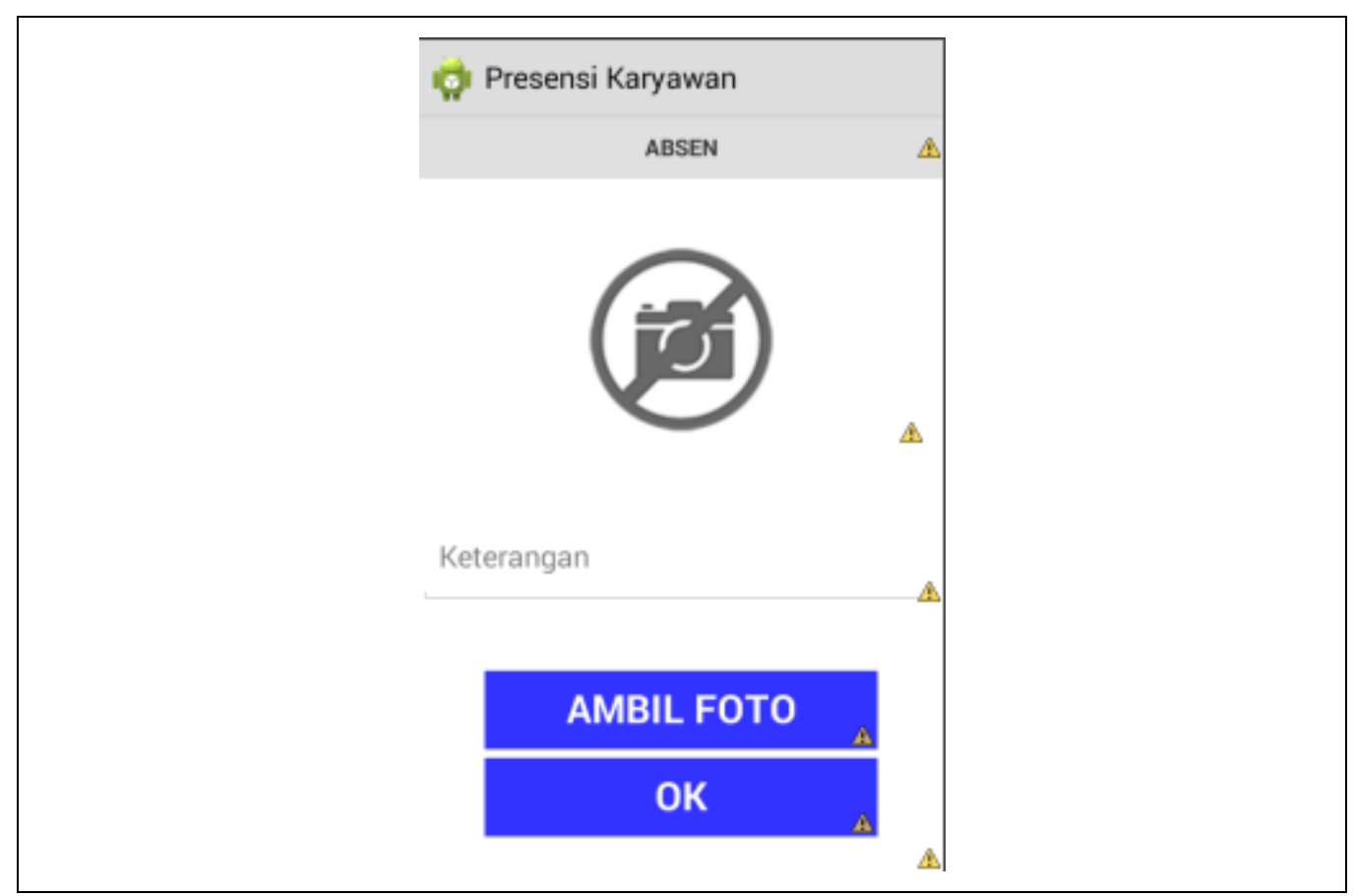

Gambar 4.13 Halaman Absen

Jika diklik tombol foto maka akan tampil halaman untuk melakukan pengambilan gambar pada kamera hp Anda. Setelah dilakukan pengambilan gambar maka akan tampi hasil 
gambar yang diambil, dihalaman ini petugas monitoring melakukan penginputan keterangan dan langsung melakukan pengiriman absensi.

\subsection{Pengujian Pengguna}

Bagian ini akan memuat penjelasan mengenai pengujian terhadap perangkat lunak yang telah diimplementasikan. Hal-hal yang akan dibahas antara lain adalah tujuan pengujian, pengujian sistem dan analisis hasil pengujian.

\subsubsection{Tujuan Pengujian}

Tujuan dilakukannya pengujian adalah untuk mengetahui apakah aplikasi telah berjalan sesuai dengan sasaran pembuatan aplikasi, yaitu menguji apakah sistem monitoring presensi karyawan pemasaran dalam bentuk mobile android telah berjalan dengan baik atau tidak.

\subsubsection{Pengujian Sistem}

Peneliti melakukan pengujian BlackBox berdasarkan 2 aktor seperti Admin dan Karyawan.

\subsubsection{Pengujian Sistem BlackBox}

a. Pengujian Sistem Aktor Admin (Web)

Tabel 4.1 Hasil Pengujian sistem Aktor Admin

\begin{tabular}{|c|c|c|c|c|c|c|c|c|c|}
\hline \multirow[t]{2}{*}{ NNO } & \multirow{2}{*}{$\begin{array}{l}\text { Tahap } \\
\text { Menjalankan } \\
\text { Aplikasi }\end{array}$} & \multirow[t]{2}{*}{$\begin{array}{l}\text { Tahap } \quad \text { Aplikasi } \\
\text { Proses }\end{array}$} & \multicolumn{3}{|c|}{ Berhasil } & \multicolumn{3}{|c|}{$\begin{array}{l}\text { Tidak } \\
\text { Berhasil }\end{array}$} & \multirow[t]{2}{*}{ Keterangan } \\
\hline & & & $\begin{array}{l}\mathbf{V} \\
\mathbf{1}\end{array}$ & $\begin{array}{l}\mathrm{V} \\
\mathbf{2}\end{array}$ & $\begin{array}{l}\mathbf{V} \\
\mathbf{3}\end{array}$ & $\begin{array}{l}\mathrm{V} \\
\mathbf{1}\end{array}$ & $\begin{array}{l}\mathrm{V} \\
\mathbf{2}\end{array}$ & $\begin{array}{l}\mathbf{V} \\
\mathbf{3}\end{array}$ & \\
\hline 11. & $\begin{array}{l}\text { Menjalankan } \\
\text { menu Login } \\
\text { saat pengguna } \\
\text { pertama kali } \\
\text { memulai } \\
\text { aplikasi }\end{array}$ & $\begin{array}{l}\text { Pada saat pengguna } \\
\text { menjalankan aplikasi } \\
\text { pertama kali akan } \\
\text { muncul logindengan } \\
\text { inputan username dan } \\
\text { password serta tombol } \\
\text { Masuk. }\end{array}$ & $\square$ & $\begin{array}{l}\checkmark \\
\checkmark\end{array}$ & $\begin{array}{l}\checkmark \\
\checkmark\end{array}$ & & & & $\begin{array}{l}\text { Berhasil karena } \\
\text { aplikasi telah dapat } \\
\text { menampilkan login. }\end{array}$ \\
\hline 22. & $\begin{array}{l}\text { Menampilkan } \\
\text { menu } \\
\text { dashboard } \\
\text { saat pengguna } \\
\text { sudah } \\
\text { melakukan } \\
\text { login. }\end{array}$ & $\begin{array}{lr}\text { Pada saat pengguna } \\
\text { berhasil login akan } \\
\text { muncul } & \text { menu } \\
\text { dashboard } & \text { sesuai } \\
\text { dengan } & \text { otoritas } \\
\text { pengguna yang login. }\end{array}$ & $\square$ & $\square$ & $\square$ & & & & $\begin{array}{l}\text { Berhasil karena } \\
\text { aplikasi telah dapat } \\
\text { menampilkan } \\
\text { halaman dashboard. }\end{array}$ \\
\hline 33. & $\begin{array}{l}\text { Menjalankan } \\
\text { menu } \\
\text { Monitoring }\end{array}$ & $\begin{array}{l}\text { Pada saat pengguna } \\
\text { Staff Admin menekan } \\
\text { menu Monitoring }\end{array}$ & $\square$ & $\square$ & $\square$ & & & & $\begin{array}{l}\text { Berhasil karena } \\
\text { aplikasi telah dapat } \\
\text { menampilkan data } \\
\text { monitoring. }\end{array}$ \\
\hline 44. & $\begin{array}{l}\text { Menjalankan } \\
\text { menu } \\
\text { Pengguna }\end{array}$ & $\begin{array}{l}\text { Pada saat pengguna } \\
\text { Staff Admin menekan } \\
\text { menu Pengguna }\end{array}$ & $\square$ & $\square$ & $\square$ & & & & $\begin{array}{l}\text { Berhasil karena } \\
\text { aplikasi telah dapat } \\
\text { menampilkan data } \\
\text { pengguna. }\end{array}$ \\
\hline
\end{tabular}




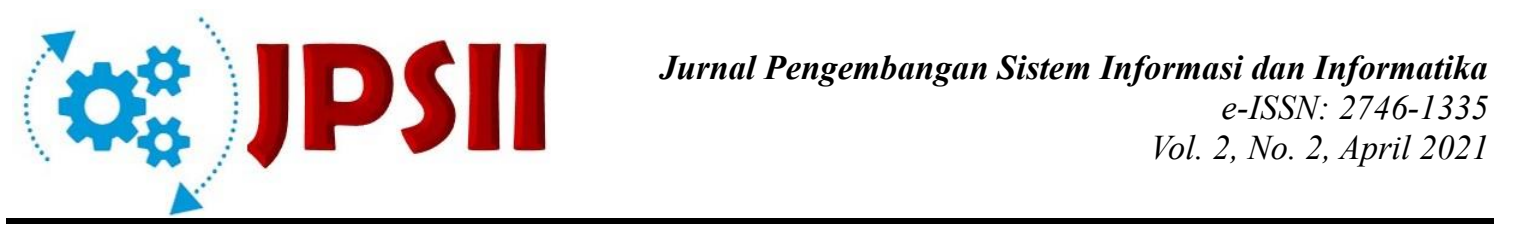

\begin{tabular}{|c|c|c|c|c|c|c|c|c|c|}
\hline \multirow[t]{2}{*}{ NNO } & \multirow{2}{*}{$\begin{array}{l}\text { Tahap } \\
\text { Menjalankan } \\
\text { Aplikasi }\end{array}$} & \multirow[t]{2}{*}{$\begin{array}{l}\text { Tahap Aplikasi } \\
\text { Proses }\end{array}$} & \multicolumn{3}{|c|}{ Berhasil } & \multicolumn{3}{|c|}{$\begin{array}{l}\text { Tidak } \\
\text { Berhasil }\end{array}$} & \multirow[t]{2}{*}{ Keterangan } \\
\hline & & & $\begin{array}{l}V \\
1\end{array}$ & $\begin{array}{l}\mathbf{V} \\
\mathbf{2}\end{array}$ & $\begin{array}{l}\mathbf{V} \\
\mathbf{3}\end{array}$ & $\begin{array}{l}\mathbf{V} \\
\mathbf{1}\end{array}$ & $\begin{array}{l}V \\
2\end{array}$ & $\begin{array}{l}\mathbf{V} \\
\mathbf{3}\end{array}$ & \\
\hline 55. & $\begin{array}{l}\text { Simpan data } \\
\text { pengguna } \\
\text { dengan } \\
\text { menekan } \\
\text { tombol } \\
\text { Tambah.. }\end{array}$ & $\begin{array}{l}\text { Pada saat pengguna } \\
\text { Staff Administrator } \\
\text { menekan tombol } \\
\text { Tambah, maka akan } \\
\text { menampilkan } \\
\text { halaman input data } \\
\text { pengguna. }\end{array}$ & $\square$ & $\square$ & $\square$ & & & & $\begin{array}{l}\text { Berhasil karena } \\
\text { aplikasi dapat } \\
\text { menampilkan } \\
\text { halaman input data } \\
\text { pengguna, dan } \\
\text { menyimpan data } \\
\text { pengguna baru. }\end{array}$ \\
\hline 56. & $\begin{array}{l}\text { Hapus data } \\
\text { pengguna } \\
\text { dengan } \\
\text { menekan } \\
\text { tombol aksi } \\
\text { Hapus. }\end{array}$ & $\begin{array}{l}\text { Pada saat pengguna } \\
\text { menekan tombol aksi } \\
\text { Hapus maka akan } \\
\text { tampil pesan bahwa } \\
\text { data pengguna akan } \\
\text { dihapus. }\end{array}$ & $\stackrel{O}{\checkmark}$ & $\stackrel{\bigcirc}{\checkmark}$ & $\stackrel{\bigcirc}{\checkmark}$ & & & & $\begin{array}{lr}\text { Berhasil } & \text { karena } \\
\text { aplikasi } & \text { dapat } \\
\text { menampilkan } & \text { pesan } \\
\text { peringatan } & \text { dan } \\
\text { menghapus } & \text { data } \\
\text { pengguna. } & \end{array}$ \\
\hline 77. & $\begin{array}{l}\text { Menjalankan } \\
\text { menu Akun } \\
\text { Saya }\end{array}$ & $\begin{array}{l}\text { Pada saat pengguna } \\
\text { Staff Administrator } \\
\text { menekan menu Akun } \\
\text { Saya }\end{array}$ & $\stackrel{\bigcirc}{\checkmark}$ & $\stackrel{\bigcirc}{\checkmark}$ & $\stackrel{O}{\checkmark}$ & & & & $\begin{array}{l}\text { Berhasil karena } \\
\text { aplikasi telah dapat } \\
\text { menampilkan data } \\
\text { Akun Saya. }\end{array}$ \\
\hline 88. & $\begin{array}{l}\text { Ubah } \\
\text { password } \\
\text { dengan } \\
\text { menjalankan } \\
\text { menu Ubah } \\
\text { Passsword. }\end{array}$ & $\begin{array}{l}\text { Pada saat pengguna } \\
\text { menekan menu Ubah } \\
\text { Password, maka akan } \\
\text { menampilkan } \\
\text { halaman ubah } \\
\text { password. }\end{array}$ & $\stackrel{O}{\checkmark}$ & $\stackrel{\bigcirc}{\checkmark}$ & $\underset{\checkmark}{O}$ & & & & $\begin{array}{lr}\text { Berhasil } & \text { karena } \\
\text { aplikasi } & \text { dapat } \\
\text { menampilkan } & \\
\text { halaman } & \text { ubah } \\
\text { password. } & \end{array}$ \\
\hline 99. & $\begin{array}{l}\text { Menjalankan } \\
\text { menu } \\
\text { Karyawan }\end{array}$ & $\begin{array}{l}\text { Pada saat pengguna } \\
\text { Staff Adminmenekan } \\
\text { menu Karyawan }\end{array}$ & $\stackrel{O}{\checkmark}$ & $\stackrel{\mathrm{O}}{\checkmark}$ & $\stackrel{\bigcirc}{\checkmark}$ & & & & $\begin{array}{l}\text { Berhasil karena } \\
\text { aplikasi telah dapat } \\
\text { menampilkan data } \\
\text { Karyawan. }\end{array}$ \\
\hline 110. & $\begin{array}{l}\text { Simpan data } \\
\text { karyawan } \\
\text { dengan } \\
\text { menekan } \\
\text { tombol } \\
\text { Tambah.. }\end{array}$ & $\begin{array}{l}\text { Pada saat pengguna } \\
\text { Staff Admin menekan } \\
\text { tombol Tambah, maka } \\
\text { akan menampilkan } \\
\text { halaman input data } \\
\text { karyawan. }\end{array}$ & $\begin{array}{l}O \\
\checkmark\end{array}$ & $\stackrel{\mathrm{O}}{\checkmark}$ & $\begin{array}{l}0 \\
\checkmark\end{array}$ & & & & $\begin{array}{l}\text { Berhasil karena } \\
\text { aplikasi dapat } \\
\text { menampilkan } \\
\text { halaman input data } \\
\text { karyawan, dan } \\
\text { menyimpan data } \\
\text { karyawan baru. }\end{array}$ \\
\hline 111. & $\begin{array}{l}\text { Ubah data } \\
\text { karyawan } \\
\text { dengan } \\
\text { menekan } \\
\text { tombol aksi } \\
\text { Ubah. }\end{array}$ & $\begin{array}{l}\text { Pada saat pengguna } \\
\text { Staff Admin menekan } \\
\text { tombol Ubah pada } \\
\text { halaman karyawan } \\
\text { maka akan } \\
\text { menampilkan } \\
\text { halaman ubah data } \\
\text { karyawan. }\end{array}$ & $\stackrel{O}{\checkmark}$ & $\stackrel{\bigcirc}{\checkmark}$ & $\stackrel{O}{\checkmark}$ & & & & $\begin{array}{l}\text { Berhasil karena } \\
\text { aplikasi dapat } \\
\text { menampilkan } \\
\text { halaman ubah data } \\
\text { karyawan. }\end{array}$ \\
\hline 112. & $\begin{array}{l}\text { Hapus data } \\
\text { karyawan } \\
\text { dengan } \\
\text { menekan } \\
\text { tombol aksi }\end{array}$ & $\begin{array}{l}\text { Pada saat Staff Adm } \\
\text { menekan tombol aksi } \\
\text { Hapus maka akan } \\
\text { tampil pesan bahwa } \\
\text { data karyawan akan }\end{array}$ & $\stackrel{O}{\checkmark}$ & $\stackrel{\bigcirc}{\checkmark}$ & $\underset{\checkmark}{O}$ & & & & $\begin{array}{lr}\text { Berhasil } & \text { karena } \\
\text { aplikasi } & \text { dapat } \\
\text { menampilkan } & \text { pesan } \\
\text { peringatan } & \text { dan } \\
\text { menghapus } & \text { data } \\
\end{array}$ \\
\hline
\end{tabular}




\begin{tabular}{|c|c|c|c|c|c|c|c|c|c|}
\hline \multirow[t]{3}{*}{ NNO } & \multirow{2}{*}{$\begin{array}{l}\text { Tahap } \\
\text { Menjalankan } \\
\text { Aplikasi }\end{array}$} & \multirow[t]{2}{*}{$\begin{array}{l}\text { Tahap } \\
\text { Proses }\end{array}$} & \multicolumn{3}{|c|}{ Berhasil } & \multicolumn{3}{|c|}{$\begin{array}{l}\text { Tidak } \\
\text { Berhasil }\end{array}$} & \multirow[t]{2}{*}{ Keterangan } \\
\hline & & & $\begin{array}{l}V \\
1\end{array}$ & $\begin{array}{l}\mathrm{V} \\
2\end{array}$ & $\begin{array}{l}\mathbf{V} \\
\mathbf{3}\end{array}$ & $\begin{array}{l}V \\
1\end{array}$ & $\begin{array}{l}\text { V } \\
2\end{array}$ & $\begin{array}{l}\text { V } \\
3\end{array}$ & \\
\hline & Hapus. & dihapus. & & & & & & & karyawan. \\
\hline 113. & $\begin{array}{l}\text { Menampilkan } \\
\text { laporan } \\
\text { periode }\end{array}$ & $\begin{array}{l}\text { Pada saat Staff Admin } \\
\text { memilih menu laporan } \\
\text { periode, maka akan } \\
\text { tampil halaman } \\
\text { menentukan periode } \\
\text { tanggal. }\end{array}$ & $\stackrel{0}{\checkmark}$ & $\stackrel{0}{\checkmark}$ & $\stackrel{0}{\checkmark}$ & & & & $\begin{array}{lr}\text { Berhasil karena } \\
\text { aplikasi dapat } \\
\text { menampilkan } \\
\text { laporan periode } \\
\text { monitoring presensi. }\end{array}$ \\
\hline
\end{tabular}

\section{b. Pengujian Sistem Aktor Karyawan (Android)}

Tabel 4.2 Hasil Pengujian sistem Aktor Karyawan

\begin{tabular}{|c|c|c|c|c|c|c|c|c|c|}
\hline \multirow[t]{2}{*}{ NNO } & \multirow{2}{*}{$\begin{array}{l}\text { Tahap } \\
\text { Menjalankan } \\
\text { Aplikasi }\end{array}$} & \multirow[t]{2}{*}{$\begin{array}{l}\text { Tahap Aplikasi } \\
\text { Proses }\end{array}$} & \multicolumn{3}{|c|}{ Berhasil } & \multicolumn{3}{|c|}{$\begin{array}{l}\text { Tidak } \\
\text { Berhasil }\end{array}$} & \multirow[t]{2}{*}{ Keterangan } \\
\hline & & & $\begin{array}{l}\mathbf{V} \\
1\end{array}$ & $\begin{array}{l}\mathbf{V} \\
\mathbf{2}\end{array}$ & $\begin{array}{l}\mathbf{V} \\
\mathbf{3}\end{array}$ & $\begin{array}{l}V \\
1\end{array}$ & $\begin{array}{l}\mathrm{V} \\
2\end{array}$ & $\begin{array}{l}\mathbf{V} \\
\mathbf{3}\end{array}$ & \\
\hline 11. & $\begin{array}{l}\text { Menampilkan } \\
\text { halaman } \\
\text { utama pada } \\
\text { saat program } \\
\text { pertama kali } \\
\text { dijalankan }\end{array}$ & $\begin{array}{l}\text { Pada saat pengguna } \\
\text { menjalankan aplikasi } \\
\text { pertama kali akan } \\
\text { muncul halaman } \\
\text { login. }\end{array}$ & $\stackrel{?}{\checkmark}$ & $\stackrel{\mathrm{O}}{\checkmark}$ & $\stackrel{\bigcirc}{\checkmark}$ & & & & $\begin{array}{l}\text { Berhasil karena } \\
\text { aplikasi telah dapat } \\
\text { menampilkan } \\
\text { halamanlogin. }\end{array}$ \\
\hline 22. & $\begin{array}{l}\text { Melakukan } \\
\text { Login dengan } \\
\text { memasukkan } \\
\text { username dan } \\
\text { password. }\end{array}$ & $\begin{array}{lr}\text { Pada saat pengguna } \\
\text { menginputkan } \\
\text { username r dan } \\
\text { password r } \\
\text { menekan } & \text { tombol } \\
\text { Login. } & \end{array}$ & $\stackrel{?}{\checkmark}$ & $\stackrel{O}{\checkmark}$ & $\stackrel{0}{\checkmark}$ & & & & $\begin{array}{l}\text { Berhasil karena } \\
\text { aplikasi telah dapat } \\
\text { menampilkan } \\
\text { halaman utama. }\end{array}$ \\
\hline 33. & $\begin{array}{l}\text { Menampilkan } \\
\text { halaman } \\
\text { absen }\end{array}$ & $\begin{array}{l}\text { Pada saat pengguna } \\
\text { menekkan menu absen } \\
\text { untuk mengambil foto. }\end{array}$ & $\stackrel{\bigcirc}{\checkmark}$ & $\stackrel{\mathrm{O}}{\checkmark}$ & $\stackrel{\bigcirc}{\checkmark}$ & & & & $\begin{array}{l}\text { Berhasil karena } \\
\text { aplikasi telah dapat } \\
\text { menampilkan } \\
\text { halaman } \\
\text { pengambilan foto } \\
\text { atau kamera. }\end{array}$ \\
\hline 44. & $\begin{array}{l}\text { Menginputka } \\
\mathrm{n} \text { data absen }\end{array}$ & $\begin{array}{l}\text { Pada saat karyawan } \\
\text { berhasil mengambil } \\
\text { gambar, dilanjutkan } \\
\text { dengan menginputkan } \\
\text { data absensi. }\end{array}$ & $\stackrel{\bigcirc}{\checkmark}$ & $\stackrel{\mathrm{O}}{\checkmark}$ & $\stackrel{\bigcirc}{\checkmark}$ & & & & $\begin{array}{lr}\text { Berhasil } & \text { karena } \\
\text { karyawan dapat } \\
\text { melakaukan absensi }\end{array}$ \\
\hline
\end{tabular}




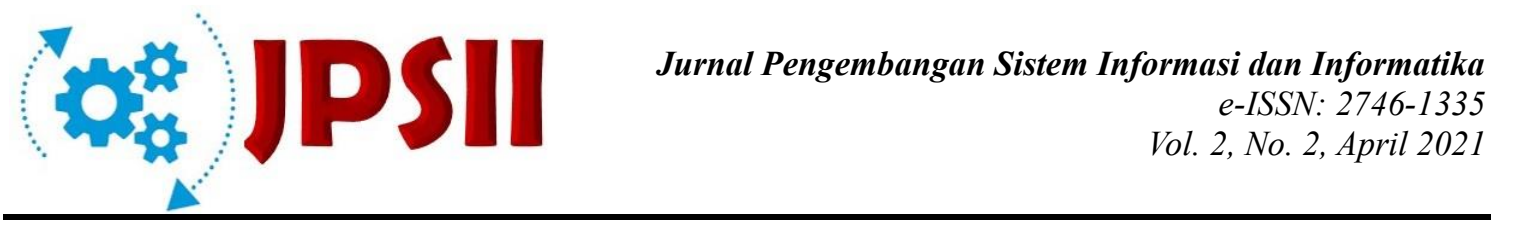

\begin{tabular}{|c|c|c|c|c|c|c|c|c|c|}
\hline \multirow[t]{2}{*}{ NNO } & \multirow{2}{*}{$\begin{array}{l}\text { Tahap } \\
\text { Menjalankan } \\
\text { Aplikasi }\end{array}$} & \multirow[t]{2}{*}{$\begin{array}{l}\text { Tahap } \quad \text { Aplikasi } \\
\text { Proses }\end{array}$} & \multicolumn{3}{|c|}{ Berhasil } & \multicolumn{3}{|c|}{$\begin{array}{l}\text { Tidak } \\
\text { Berhasil }\end{array}$} & \multirow[t]{2}{*}{ Keterangan } \\
\hline & & & $\begin{array}{l}V \\
1\end{array}$ & $\begin{array}{l}V \\
2\end{array}$ & $\begin{array}{l}\mathbf{V} \\
\mathbf{3}\end{array}$ & $\begin{array}{l}\text { V } \\
1\end{array}$ & $\begin{array}{l}V \\
2\end{array}$ & $\begin{array}{l}\mathbf{V} \\
\mathbf{3}\end{array}$ & \\
\hline 55. & $\begin{array}{l}\text { Mengirimkan } \\
\text { data absensi }\end{array}$ & $\begin{array}{l}\text { Pada saat karyawan } \\
\text { selesai melakukan } \\
\text { penginputan data } \\
\text { absensi, dilanjutkan } \\
\text { dengan mengirimkan } \\
\text { data asben ke server. }\end{array}$ & $\begin{array}{l}O \\
\checkmark\end{array}$ & $\stackrel{\bigcirc}{\checkmark}$ & $\begin{array}{l}0 \\
\checkmark\end{array}$ & & & & $\begin{array}{l}\text { Berhasil karena } \\
\text { aplikasi telah dapat } \\
\text { mengirimkan data } \\
\text { absensi karyawan. }\end{array}$ \\
\hline
\end{tabular}

\section{Kesimpulan}

1. Berdasarkan hasil penelitian dan pembahasan pada sistem monitoring presensi karyawan pemasaran dalam bentuk mobile android ini, maka dapat ditarik kesimpulan sebagai berikut:

2. Dari pengujian black box yang telah dilakukan maka dapat disimpulkan bahwa sistem monitoring presensi karyawan dapat berjalan dengan baik dan tidak ada permasalahan.

3. teknologi $G P S$ dapat memberikan informasi titik lokasi pengambilan gambar foto karyawan sehingga mudah mengetahui posisi absen karyawan pada saat itu untuk menghindari kecurangan dalam absensi.

\section{Referensi}

Antoni, D., \& Akbar, M. (2019). E-supply chain management value concept for the palm oil industry. Jurnal Sistem Informasi, 15(2), 15-29.

Antoni, D., Fikari, D., \& Akbar, M. (2018). The readiness of palm oil industry in enterprise resource planning. Telkomnika, 16(6), 2692-2702.

Antoni, D., Herdiansyah, M. I., Akbar, M., \& Sumitro, A. (2021). Pengembangan Infrastruktur Jaringan Untuk Meningkatkan Pelayanan Publik di Kota Palembang. JURNAL MEDIA INFORMATIKA BUDIDARMA, 5(4), 1652-1659. 
Antoni, D., Jie, F., \& Abareshi, A. (2020). Critical factors in information technology capability for enhancing firm's environmental performance: case of Indonesian ICT sector. International Journal of Agile Systems and Management, 13(2), 159-181.

Departemen Pendidikan Nasional. 2008. Kamus Besar Bahasa Indonesia Pusat Bahasa Edisi Keempat. 2008. Jakarta: PT Gramedia Pustaka Utama

Fauzi, F., Dencik, A. B., \& Asiati, D. I. (2019). Metodologi Penelitian untuk manajemen dan akuntansi. Jakarta: Salemba Empat.

Felker, Donn. 2011. Android Applications Development For Dummies. Willey Publishing Inc. Canada

Hermawan S, Stephanus. 2011. Mudah Membuat Aplikasi Android. Binus University

Manav Singhal, Anupam Shukla. 2012. Implementation of Location based Service in Android using GPS and Web Service. India

Priyanka Shah, Ruta Gadgil, Neha Tamhankar. 2017. Location Based Reminder Using GPS For Mobile (Android). India

Safaat, N. (2012). Pemograman Aplikasi Mobile Smartphone dan Tablet PC Berbasis Android. Bandung: Penerbit Informatika.

Tamada, R. 2012. Android JSON Parsing Tutorial.

Tohari, Ahmad. 2016. Pemahaman Praktis Manajemen Sumber Daya Manusia. Bandung: Mandar Maju.

Winarko, E. 2006. Perancangan Database Dengan PowerDesigner 6.32. Jakarta: Prestasi Pustaka.

\section{Copyrights}

Copyright for this article is retained by the author(s), with first publication rights granted to the journal.

This is an open-access article distributed under the terms and conditions of the Creative Commons Attribution license (http://creativecommons.org/licenses/by/4.0/) 